\title{
Upregulation of Glutaredoxin-1 Activates Microglia and Promotes Neurodegeneration: Implications for Parkinson's Disease
}

\author{
Olga Gorelenkova Miller, Jessica Belle Behring, Sandra L. Siedlak, Sirui Jiang, Reiko Matsui, \\ Markus M. Bachschmid, Xiongwei Zhu, and John J. Mieyal ${ }^{1,4}$
}

\begin{abstract}
Aims: Neuroinflammation and redox dysfunction are recognized factors in Parkinson's disease (PD) pathogenesis, and diabetes is implicated as a potentially predisposing condition. Remarkably, upregulation of glutaredoxin1 (Grx1) is implicated in regulation of inflammatory responses in various disease contexts, including diabetes. In this study, we investigated the potential impact of Grx1 upregulation in the central nervous system on dopaminergic (DA) viability.

Results: Increased GLRX copy number in PD patients was associated with earlier PD onset, and Grx1 levels correlated with levels of proinflammatory tumor necrosis factor-alpha (TNF- $\alpha$ ) in mouse and human brain samples, prompting mechanistic in vitro studies. Grx1 content/activity in microglia was upregulated by lipopolysaccharide (LPS), or TNF- $\alpha$, treatment. Adenoviral overexpression of Grx1, matching the extent of induction by LPS, increased microglial activation; Grx1 silencing diminished activation. Selective inhibitors/ probes of nuclear factor $\kappa \mathrm{B}(\mathrm{NF}-\kappa \mathrm{B})$ activation revealed glrxl induction to be mediated by the Nurr $1 / \mathrm{NF}-\kappa \mathrm{B}$ axis. Upregulation of Grx1 in microglia corresponded to increased death of neuronal cells in coculture. With a mouse diabetes model of diet-induced insulin resistance, we found upregulation of Grx1 in brain was associated with DA loss (decreased tyrosine hydroxylase [TH]; diminished $\mathrm{TH}$-positive striatal axonal terminals); these effects were not seen with Grx1-knockout mice.

Innovation: Our results indicate that Grx1 upregulation promotes neuroinflammation and consequent neuronal cell death in vitro, and synergizes with proinflammatory insults to promote DA loss in vivo. Our findings also suggest a genetic link between elevated Grx1 and PD development.

Conclusion: In vitro and in vivo data suggest Grx1 upregulation promotes neurotoxic neuroinflammation, potentially contributing to PD. Antioxid. Redox Signal. 25, 967-982.
\end{abstract}

Keywords: neuroinflammation glutaredoxin, Parkinson's disease, microglia, diabetes

\section{Introduction}

$\mathbf{P}$ ARKINSON'S DISEASE (PD) is the second most common neurodegenerative disease worldwide (23). It is characterized by selective degeneration of dopaminergic (DA) neurons in the midbrain, likely beginning with axonal loss in the striatum (6). Neuroinflammation has been implicated as an important contributing factor in PD (41). Elevated cytokine concentrations and phagocytic markers, along with an increase in inflammatory microglia, have been observed in substantia nigra tissue from both chemical and genetic models of PD, and in postmortem tissue from $\mathrm{PD}$ patients (50).

Dysregulation of redox homeostasis (oxidative stress) is another recognized factor in PD pathogenesis, and its potential effects on inflammatory signaling in PD and other neurodegenerative diseases have been reviewed recently

\footnotetext{
${ }^{1}$ Department of Pharmacology, School of Medicine, Case Western Reserve University, Cleveland, Ohio.

${ }^{2}$ Vascular Biology Section, Whitaker Cardiovascular Institute, Boston University School of Medicine, Boston, Massachusetts.

${ }^{3}$ Department of Pathology, School of Medicine, Case Western Reserve University, Cleveland, Ohio.

${ }^{4}$ Louis Stokes Cleveland Veterans Administration Medical Research Center, Cleveland, Ohio.
} 


\section{Innovation}

Inflammation and redox dysregulation have been implicated in the etiology of Parkinson's disease (PD). In this study, we document a regulatory role of Grx1 in inflammatory activation of microglia and concomitant neurotoxicity. Considered along with increased susceptibility to dopaminergic neurodegeneration of vertebrates overexpressing Grx1, these data implicate Grx1 in promoting PD, a previously unrecognized contribution of Grx1 to PD etiology. Thus, our findings caution against stimulating upregulation of Grx1 in the whole brain, which has been postulated as a potential therapeutic approach for PD. Instead, elevated Grx1 is identified as a potential risk factor in PD.

(16). In this context, metabolic syndrome is of particular interest as it is characterized by increases in both oxidative stress and proinflammatory signaling (20). Furthermore, metabolic syndrome has been reported to be associated with increased risk of developing PD (56). High-fat high-sugar (HFHS) diet, used extensively to model metabolic syndrome and insulin resistance in mice $(36,54)$, has been found to worsen the effects of chemical inducers of PD, 1-methyl-4phenyl-1,2,3,6-tetrahydropyridine (MPTP) and 6-OHDA (5, $9,32)$. Hence, in the current study, we investigated the impact of HFHS on DA neuronal viability under conditions expected to promote proinflammatory activation.

Perturbation of enzymes that regulate redox homeostasis is a common consideration in both the oxidative stress and neuroinflammatory components of PD pathogenesis. Glutaredoxin-1 (Grx1), the enzyme that regulates reversible protein glutathionylation, stands out as being implicated in both the apoptotic and inflammatory signaling aspects of metabolic syndrome $(43,51)$, and of PD (16). We and others have observed that Grx1 diminution exacerbates neuronal cell death in vitro $(13,39)$ and in in vivo (18). In contrast, upregulation of Grx1 has been associated with proinflammatory activation in several other contexts.

Grx 1 is expressed abundantly in immune cells $(34,35)$, and it has been found to be upregulated in various situations where cytokine production is enhanced, such as hyperglycemia in retinal Mueller cells, a model of diabetic retinopathy (45), and in lung epithelial cells in response to various inflammatory stimuli (37). However, it has been unknown whether Grx1 plays a regulatory role in activation of microglia, the primary proinflammatory cell of the central nervous system (CNS) that is implicated in neurodegeneration.

We report here that increased GLRX copy number in PD patients corresponds to an earlier age of disease onset. At the cellular level, we found lipopolysaccharide (LPS) induces Grx1 in microglia apparently through the NF- $\kappa \mathrm{B} / \mathrm{Nurr} 1$ axis. Adenoviral-mediated overexpression of Grx1 in microglia markedly increases cytokine release and death of cocultured neurons, and mice overexpressing human Grx1 displayed an increase in brain cytokine levels. These transgenic mice also displayed DA degeneration when fed a high-fat diet. Taken together, these observations suggest that inflammation driven by Grx1 upregulation synergizes with other proinflammatory insults to promote neurotoxic inflammation, suggesting elevated Grx1 expression in the CNS as a potential risk factor for PD.

\section{Results}

Increase in GLRX copy number is associated with earlier age of $P D$ onset

Considering the potential interrelationships between inflammation, insulin resistance, oxidative stress, and PD, as well as previous observations of Grx1 upregulation in inflammatory cells, we investigated effects of GLRX copy number in PD patients. Whole genome sequence analysis of PD patients revealed six PD patients with increased GLRX
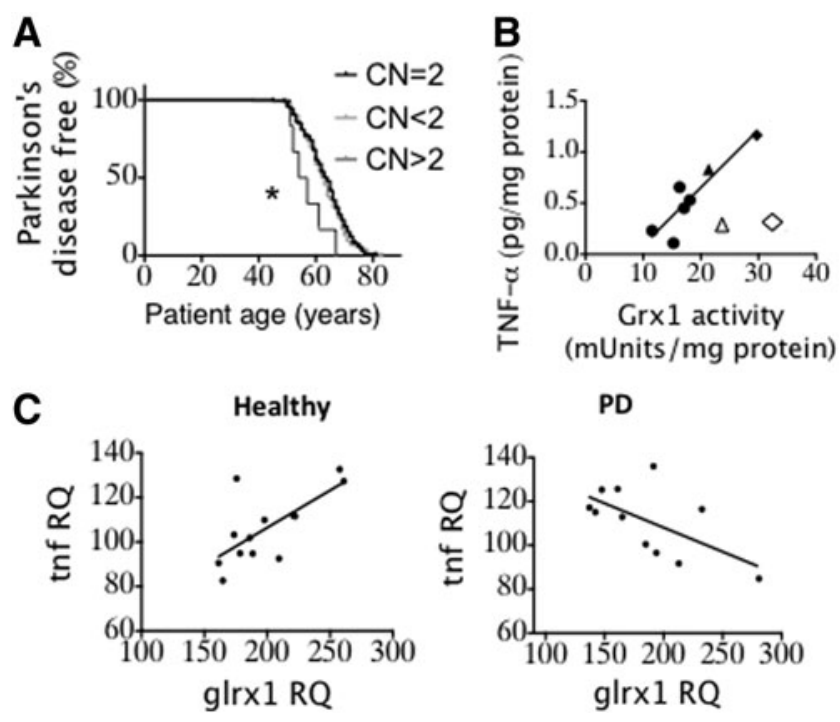

FIG. 1. In vivo relationships among Grx1, TNF- $\alpha$ and PD. (A) Decreased age of PD onset correlates with increased GLRX copy number. Age of disease onset for PD patients with varying GLRX copy numbers for patients diagnosed at age 50 or older. Differences between Kaplan-Meier curves were analyzed using the log-rank (Mantel-Cox) test, $p=0.011$ for $\mathrm{CN}=2$ versus $\mathrm{CN}>2$, hazard ratio $=0.38$ (95\% confidence interval $0.51-2.6$ ), $p=0.48$ for $\mathrm{CN}=2$ versus $\mathrm{CN}<2$, as described in the Materials and Methods section. The table (below) provides the cohort characteristics used to generate the Kaplan-Meier curves, where PD patients refer to all patients diagnosed with idiopathic PD and Healthy Controls refer to age-matched non-PD control subjects.

\begin{tabular}{|c|c|c|c|c|c|}
\hline \multirow{2}{*}{$\begin{array}{l}\text { GLRX } \\
\text { copy } \\
\text { number }\end{array}$} & \multicolumn{2}{|c|}{$P D$ patients } & \multicolumn{2}{|c|}{ Healthy controls } & \multirow{2}{*}{$\begin{array}{c}\begin{array}{c}\text { Age of } P D \\
\text { onset } \geq 50 \text { y.o. }\end{array} \\
\text { Number }\end{array}$} \\
\hline & Number & Percent & Number & Percent & \\
\hline $\mathrm{CN}<2$ & 165 & 40.6 & 62 & 36 & 13 \\
\hline $\mathrm{CN}=2$ & 235 & 57.9 & 103 & 60.6 & 197 \\
\hline $\mathrm{CN}>2$ & 6 & 1.5 & 5 & 2.9 & 6 \\
\hline
\end{tabular}

(B) Correlation of Grx1 and TNF- $\alpha$ levels in mouse brain tissue. Grx1 activity versus TNF- $\alpha$ levels $\left(R^{2}=0.81\right.$, $p=0.0025)$ for midbrain homogenates from female C57BL/6 mice, ages 4-5 months $(\diamond, \diamond)$ (young, $n=2)$; 13 months $(\boldsymbol{\Delta}$, $\Delta$ ) (middle age, $n=2$ ); and 17 months ( $\bullet$ ) (elderly, $n=6$ ). Outliers (open symbols) were not included according to the method of least-squares regression. (C) GEO accession number GSE20295. glrxl versus tnfa in healthy controls, left $\left(p=0.008, R^{2}=0.48\right)$, and $\mathrm{PD}$ patients, right $(p=0.04$, $\left.R^{2}=0.37\right)$. ${ }^{*} p<0.05$. CN, copy number; Grx1, glutaredoxin-1; $\mathrm{PD}$, Parkinson's disease; TNF- $\alpha$, tumor necrosis factor-alpha. 
copy numbers (compilation shown in legend to Fig. 1). Among all patients who were diagnosed with $\mathrm{PD}$ at 50 years of age or older, patients with increased GLRX $(\mathrm{CN}>2)$ presented with a significantly earlier age of PD onset compared to patients with normal copy number (Fig. 1A). This analysis is the first to reveal a potential genetic link between elevated Grx1 and PD (see Discussion section).

In several previous studies, the proinflammatory cytokine tumor necrosis factor- $\alpha$ (TNF- $\alpha)$ has been implicated in mediating neurodegeneration (31). Considering also previous observations relating Grx1 upregulation in immune cells to increased cytokine release, we examined the relationship between Grx 1 and TNF- $\alpha$ contents in brain tissue. Analysis of brain homogenates from mice (4-18 months of age) showed a strong correlation between TNF- $\alpha$ levels and Grx1 activity in the midbrains (Fig. 1B). Turning again to human samples, we analyzed gene expression data (57) from substantia nigra of matched controls and PD patients. A positive correlation was documented between grxl and tnfa expression in healthy controls (Fig. 1C, left), analogous to the protein data for mouse brain (Fig. 1B). However, the relationship became inverted in PD patients (Fig. 1C, right), suggesting a dysregulation of the link between Grx 1 and TNF- $\alpha$ in PD (see Discussion section). The in vivo correlations suggesting a potential link between Grx 1 and proinflammatory activation associated with PD prompted us to pursue mechanistic in vitro studies on the heretofore uninvestigated role of Grx1 in regulation of microglial activation.

\section{Inflammatory agents induce Grx1 in microglia}

LPS induces Grx1 in microglia. Since CNS inflammation promotes PD (41) and Grx1 is induced by proinflammatory stimuli in other contexts $(3,45)$, we tested LPS, which is a robust proinflammatory stimulus commonly used to activate microglia in culture (40). We found that LPS treatment of BV2 cells, used extensively as a model for microglia (40), increased Grx1 activity and content (Fig. 2A). Maximum Grx1 induction (approximately twofold) occurred at $1 \mu \mathrm{g} / \mathrm{ml}$ LPS (Fig. 2A).

Primary microglia isolated from neonatal C57BL/6 mice (Fig. 2B) and primary human microglia obtained commercially (Fig. 2C) displayed similar increases in Grx1 protein content and enzymatic activity in response to LPS, validating the use of BV2 cells as a model for microglia in this context. Levels of glrx 1 mRNA were also elevated by LPS treatment (Fig. 2D), documenting induction at the transcriptional level. Consistent with the well-known cellular function of Grx1, its induction by LPS corresponded to a decrease in global glutathionylated protein levels (Fig. 2E).

TNF- $\alpha$ induces Grx1 in microglia. Notably, TNF- $\alpha$ (10 ng/ $\mathrm{ml}$ ) induced Grx1 in BV2 cells to the same maximal extent as LPS (Fig. 3A), and $50 \mathrm{ng} / \mathrm{ml}$ TNF- $\alpha$ elicited maximal Grx1 induction in mouse primary neonatal microglia (Fig. 3B). The time course for induction of glrx 1 mRNA by TNF- $\alpha$ in BV2 cells (Fig. 3C) paralleled that by LPS (Fig. 2D), suggesting that both inflammatory stimuli induce Grx1 through a common mechanism. Treatment with increasing concentrations of TNF- $\alpha$ up to $1000 \mathrm{ng} / \mathrm{ml}$ confirmed maximum induction of glrxl mRNA also at approximately twofold (Fig. 3D).

\section{Grx1 levels in microglia govern activation}

Grx1 overexpression promotes microglial activation. To assess whether elevation of Grx 1 by itself is sufficient to drive increased cytokine release, we overexpressed Grx1 in BV2 cells using an adenoviral vector titrated to give the same extent of induction as seen with LPS treatment (Fig. 4A).
FIG. 2. LPS induces Grx1 in microglia. (A) BV2 cells treated with indicated concentrations of LPS for $24 \mathrm{~h}$. (B) C57BL/6 mouse primary neonatal microglia treated with $1 \mu \mathrm{g} / \mathrm{ml}$ LPS for $24 \mathrm{~h}$. (C) Human primary microglia (ScienCell) treated as in (B). (D) glrxl mRNA levels in cells treated with $1 \mu \mathrm{g} / \mathrm{ml}$ LPS for the indicated times. RQ, relative quantity normalized to gapdh mRNA as an internal control. (E) Glutathionylated protein levels in BV2 cells treated with $1 \mu \mathrm{g} / \mathrm{ml}$ LPS for $24 \mathrm{~h}$. All data are presented as Mean \pm SEM; $n=$ at least three independent samples, with at least two determinations of Grx1 activity and four determinations of mRNA expression. $* p<0.05 ; \quad * * p<0.01$, $* * * p<0.001$. LPS, lipopolysaccharide.
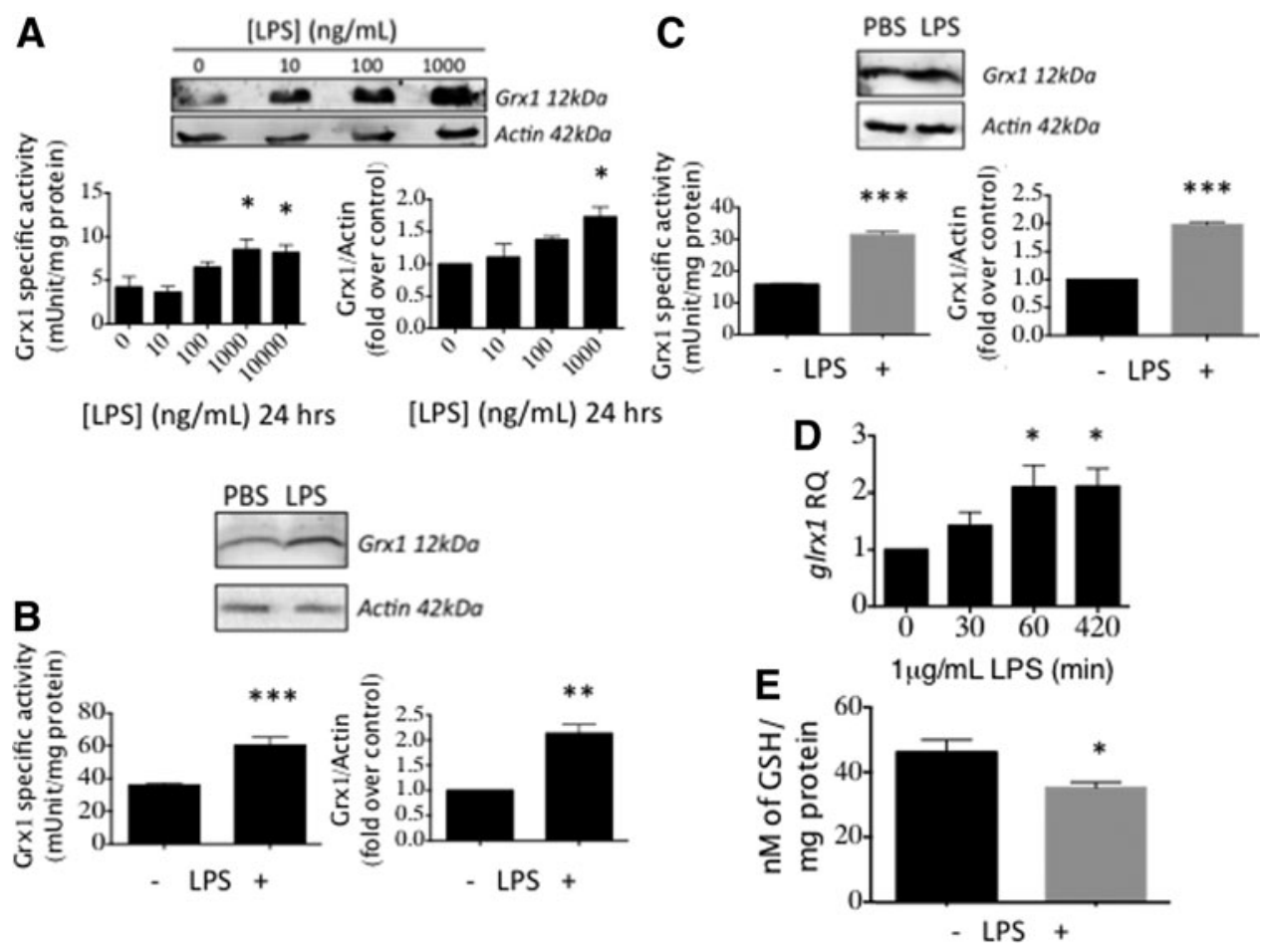




FIG. 3. TNF- $\alpha$ induces Grx1 in microglia. (A) BV2 cells treated with $10 \mathrm{ng} / \mathrm{ml} \mathrm{TNF}-\alpha$ for $12 \mathrm{~h}$. (B) Grx1specific activity was increased in C57BL/6 mouse primary neonatal microglia treated with $50 \mathrm{ng} / \mathrm{ml}$ TNF$\alpha$ for $12 \mathrm{~h}$. (C) glrx 1 mRNA levels in BV2 cells treated with indicated concentrations of TNF- $\alpha$ for $1 \mathrm{~h}$. Data are presented as Mean \pm SEM, $n=$ at least three, with at least two determinations of Grx1 activity and four determinations of mRNA expression. $* p<0.05$; $* * p<0.01$; *** $p<0.001$. (D) glrx 1 mRNA levels were increased in BV2 cells treated with $10 \mathrm{ng} / \mathrm{ml} \mathrm{TNF}-\alpha$ for the indicated times. RQ, relative quantity normalized to gapdh mRNA as an internal control. $* p<0.05$, $* * p<0.01$, compared to PBS by oneway ANOVA.

Grx1 overexpression drove increased cytokine release as documented with a cytokine ELISA panel (Fig. 4B), indicating that Grx1 induction mediates microglial activation. Moreover, Grx1 overexpression alone induced levels of interleukin (IL)-6 release indistinguishable from those seen with LPS treatment (Fig. 4B), suggesting that Grx1 induction is the main mediator of increased production of some LPSinduced cytokines.

Furthermore, Grx1 upregulation by LPS or via adenoviral overexpression led to a concomitant decrease of glutathionylation of p65 in the microglia (Fig. 4C). Since deglutathionylation of p65 has been found to correspond to increased transcriptional activity of p65 in several other contexts $(3,25,26)$, we interpret our current findings to suggest that upregulation of Grx 1 activates microglia through activating NF- $\kappa \mathrm{B}$ (see Discussion section).

Grx1 silencing decreases microglial activation in response to LPS. Diminution of Grx 1 content has been found to decrease responses of other cell types to inflammatory stimuli $(2,45)$. Therefore, we investigated whether Grx1 silencing would decrease the response of BV2 microglial cells to LPS. Grx1 knockdown $(\sim 80 \%)$ in BV2 cells (Fig. 4D) corresponded to a decrease $(\sim 60 \%)$ in IL-6 release by LPS (Fig. 4E). In contrast, we found that Grx 1 knockdown did not decrease TNF- $\alpha$ release from BV2 cells in response to LPS (data not shown).

\section{Grx1 upregulation in microglia promotes neuronal cell death in coculture}

To test whether Grx1 upregulation in microglia, corresponding to inflammatory activation, would drive loss of DA neurons, we treated BV2 cells with LPS or adenoviral-Grx1

and cocultured these microglia with SH-SY5Y cells, a human neuroblastoma cell line used extensively as a model of DA neurons (55). Grx1 induction in BV2 by either method promoted similar increases in two indicators of apoptosis in the model neurons, namely, formation of the $24 \mathrm{kDa}$ fragment of poly (ADP-ribose) polymerase (PARP) (Fig. 5A) and chromatin condensation (Fig. 5B); similar results were obtained for embryonic rat neurons (Fig. 5C). Our results suggest that Grx1 is the main driver of microglial activation associated with neurotoxic inflammation.

\section{Microglial Grx1 induction in response to LPS is regulated by the $A P-1, N F-\kappa B / N u r r 1$ axis}

Grx1 induction is mediated by both $\mathrm{AP}-1$ and NF- $\kappa \mathrm{B}$ signaling in response to LPS. In other contexts, Grx1 transcription has been interpreted to be governed by AP-1 (21) or by the canonical NF- $\kappa$ B pathway (3). LPS initiates its effects through TLR4, and stimulation of TLR4 has been shown to engage both the NF- $\kappa \mathrm{B}$ and AP-1 pathways (19); therefore, we investigated the contribution of each of these pathways to Grx1 induction in the microglia.

Using SC-514, an IKK $\beta$ inhibitor (NF- $\kappa \mathrm{B}$ pathway), and SP600125, a c-Jun N-terminal kinase (JNK) inhibitor (AP-1 pathway), we observed that both inhibitors, tested separately, in a concentration-dependent manner diminished the increase in Grx1 activity effected by LPS (Fig. 6A). We also observed that the increase of glrxl mRNA (measured $1 \mathrm{~h}$ after LPS) was essentially nullified by the presence of $0.5 \mu M$ of either inhibitor alone, or in combination (Fig. 6B). The increase in Grx1 protein content (measured $24 \mathrm{~h}$ after LPS) displayed greater inhibition by the combination of the two inhibitors than by either inhibitor alone (at $0.5 \mu M$ ) (Fig. 6C). While these data do not distinguish between synergistic or additive 

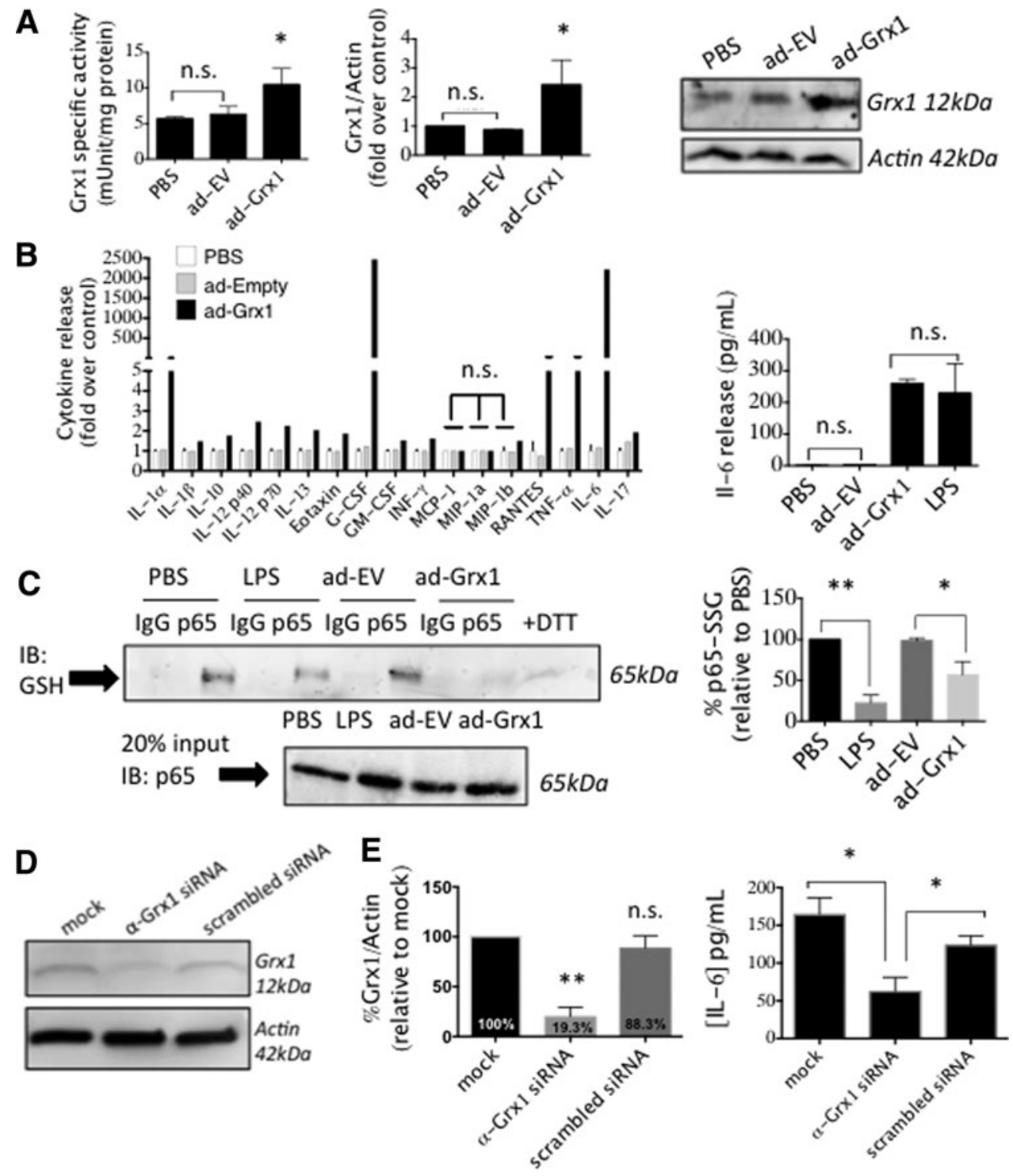

FIG. 4. Manipulation of Grx1 content in BV2 cells. (A) BV2 cells infected with ad-Grx1 (MOI 200) or ad-EV (empty vector, MOI 200) for $2 \mathrm{~h}$, then further cultured for $24 \mathrm{~h}$. Shown are Grx1-specific activity (left); Relative Grx 1 content (middle); representative Western blot (right). (B) At the left, multiplex analysis of cell media samples from the following treatments, PBS, (white bars); ad-EV (MOI 200), (gray bars); or ad-Grx1 (MOI 200), (black bars); at the right, IL-6 levels in the media of cells treated with PBS; ad-EV (MOI 200); ad-Grx1 (MOI 200); or LPS, $1 \mu \mathrm{g} / \mathrm{ml}$ LPS for $24 \mathrm{~h}$. All values in (B) for ad-Grx 1 or LPS, except where indicated, are significantly different from control, at $p<0.05$; n.s., not significant. (C) Decrease in glutathionylation of p65 was found when analyzed after $24 \mathrm{~h}$ treatment of BV2 cells with LPS. At the left, representative immunoprecipitation of p65 from BV2 cells infected with ad-Grx1 (MOI 200) or ad-EV (MOI 200), or stimulated with LPS and then probed with anti-GSH antibody; bottom left, $20 \%$ immunoprecipitation input, probed for p65. At the right, quantification of $\%$ glutathionylation of p65 remaining, analyzed after treatment of BV $2 \mathrm{cells}$ with $1 \mu \mathrm{g} / \mathrm{ml} \mathrm{LPS}$ for $24 \mathrm{~h}$ (compared to PBS-treated cells), or with ad-Grx1 MOI 200 (compared to ad-EV, MOI 200). Data bars represent Mean \pm SEM, $n=$ at least three, with at least two determinations of Grx1 activity and three determinations of cytokine levels. ${ }^{*} p<0.05$; $* * p<0.01$. (D) Western blot of BV2 cells transfected with mock transfection (oligofectamine only), anti-Grx1 siRNA, or scrambled siRNA. (E) Densitometry showing extent of Grx1 diminution; $p$-value calculated using one-way ANOVA, $n=3 \pm$ SEM; $* * p<0.01$, n.s., not significant. Right: IL-6 release after $24 \mathrm{~h}$ stimulation with $1 \mu \mathrm{g} / \mathrm{ml} \mathrm{LPS}$ of cells in (A), $n=3 \pm$ SEM; $* p<0.05$. IL, interleukin.

effects of the respective inhibitors, it is evident that glrxl induction in microglia upon LPS stimulation is mediated by both AP-1 and NF- $\kappa$ B pathways.

Nurr1/p65 axis mediates LPS-initiated induction of Grx1. The Nurr1/CoREST corepressor complex has been reported to regulate expression of NF- $\kappa \mathrm{B}$ proinflammatory target genes in microglia and astrocytes (40). Accordingly, we investigated whether the NF- $\kappa \mathrm{B} / \mathrm{Nurr} 1$ axis is involved in regulating glrxl transcription. The p65 subunit of NF- $\kappa \mathrm{B}$ displayed increased binding to the putative NF- $\kappa \mathrm{B}$ target region of the GLRX promoter following $4 \mathrm{~h}$ of treatment with 
A
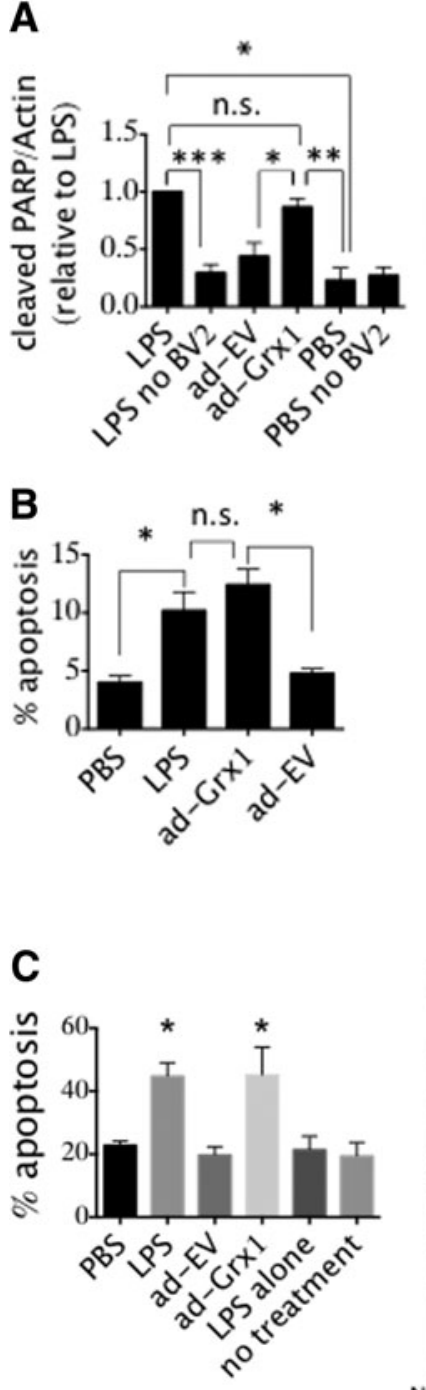

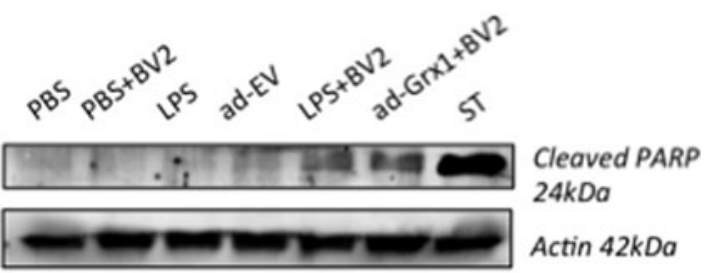

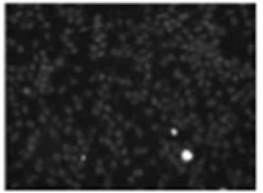

SH-SY5Y, BV2 + PBS

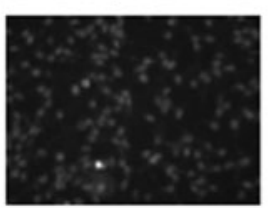

SH-SY5Y, BV2 + Ad-EV SH-SY5Y, BV2 + Ad-Grx1



Neurons, BV2+ PBS

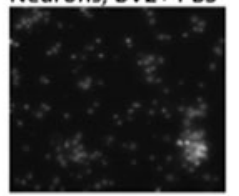

Neurons, BV2+ad-Grx

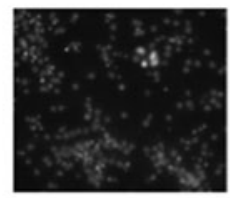

Neurons, BV2+LPS

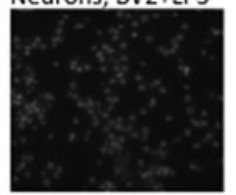

Neurons + LPS

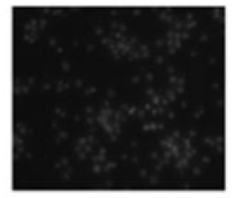

Neurons, BV2+ad-EV

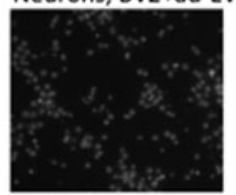

Neurons
FIG. 5. Grx1 upregulation in the microglia induces neuronal apoptosis. SH-SY5Y human neuroblastoma cells or primary rat embryonic neurons were cocultured with BV2 cells infected with ad-Grx1 (MOI 200) or ad-EV (MOI 200), or activated with $1 \mu \mathrm{g} / \mathrm{ml}$ LPS for $48 \mathrm{~h}$. Neurons and BV2 cells were separated by a nylon mesh with a $0.2 \mu$ m diameter pore. (A) PARP cleavage (26 kDa fragment) and (B) apoptotic nuclei formation as measured by Hoechst 33342 stain. $\mathrm{ST}=1 \mu M$ staurosporine, used as a positive control for cell death. Data bars represent Mean \pm SEM, $n=$ at least three, with three independent blinded counts of Hoechst-stained nuclei. $* p<0.05, * * p<0.005, * * * p<$ 0.001 ; n.s., not significant. (C) Hoechst staining of primary embryonic rat neurons. $* p<0.05$ by one-way ANOVA compared to PBS sample. PARP, poly (ADP-ribose) polymerase.
LPS (Fig. 7A), analogous to previous observations with RAW264.7 macrophage cells (3). Nurr1 binding to the same region on the GLRX promoter decreased at $4 \mathrm{~h}$ of LPS treatment (Fig. 7B), consistent with the proposed mechanism of Nurr1 enhancing p65 clearance from target sites (40).

Moreover, treatment with an inhibitor of G9a, a lysine methyltransferase that is part of the Nurr1/CoREST complex (40), led to enhanced glrx 1 induction by LPS, approximately twofold greater than with LPS treatment alone (Fig. 7C). As a positive control for the G9a inhibitor, we also documented enhanced expression of $i l 1 b$, a known target of Nurr1/CoREST repression (Fig. 7D). These results indicate, for the first time, that the Nurr1/CoREST complex is involved in repression of glrxl induction.

\section{Grx1 overexpression in vivo displays a proinflammatory phenotype and promotes $D A$ neuronal loss in a model of metabolic syndrome}

Mice overexpressing Grx1 display elevated cytokine levels in the CNS. Considering the proinflammatory effect of Grx1 overexpression in microglia in vitro (Fig. 4), we investigated whether Grx1 overexpression in vivo would promote CNS inflammation. Using C57BL/6 $\mathrm{J}^{\mathrm{hGrx} 1 \mathrm{TG}}$ transgenic mice, which display double the amount of Grx 1 content and activity compared to WT (1), we observed elevated levels of TNF- $\alpha$ and IL6 in brain homogenates compared to $\mathrm{C} 57 \mathrm{BL} / 6 \mathrm{~J}^{\mathrm{WT}}$ controls (Fig. 8A). This result suggests that Grx 1 overexpression in the CNS produces a proinflammatory phenotype.

Mice overexpressing Grx1 display DA neuronal loss when maintained on HFHS. Metabolic syndrome is characterized as a proinflammatory condition (20), potentially linked to increased risk of PD (56), and a HFHS diet has been documented to induce metabolic syndrome $(36,54)$. Accordingly, we hypothesized that the C57BL/6 $\mathrm{J}^{\mathrm{hGrx} 1 \mathrm{TG}}$ mice, which display increased basal CNS inflammation (Fig. 8A), would be predisposed to DA degeneration on a HFHS diet. Indeed, C57BL/6J ${ }^{\text {hGrx1TG }}$ mice on the HFHS diet displayed a significant decrease in brain tyrosine hydroxylase (TH) levels compared to $\mathrm{C} 57 \mathrm{BL} / 6 \mathrm{~J}^{\mathrm{hGrx} 1 \mathrm{TG}}$ mice on a control diet, or $\mathrm{C} 57 \mathrm{BL} / 6 \mathrm{~J}^{\mathrm{WT}}$ mice on either a control or HFHS diet (Fig. 8B). Moreover, C57BL/6 $\mathrm{J}^{\mathrm{hGrx} 1 \mathrm{TG}}$ mice on HFHS displayed loss of $\mathrm{TH}$ immunoreactivity in the striatal axonal terminals when compared to C57BL/6J ${ }^{\mathrm{WT}}$ mice on the same diet (Fig. 8C). 

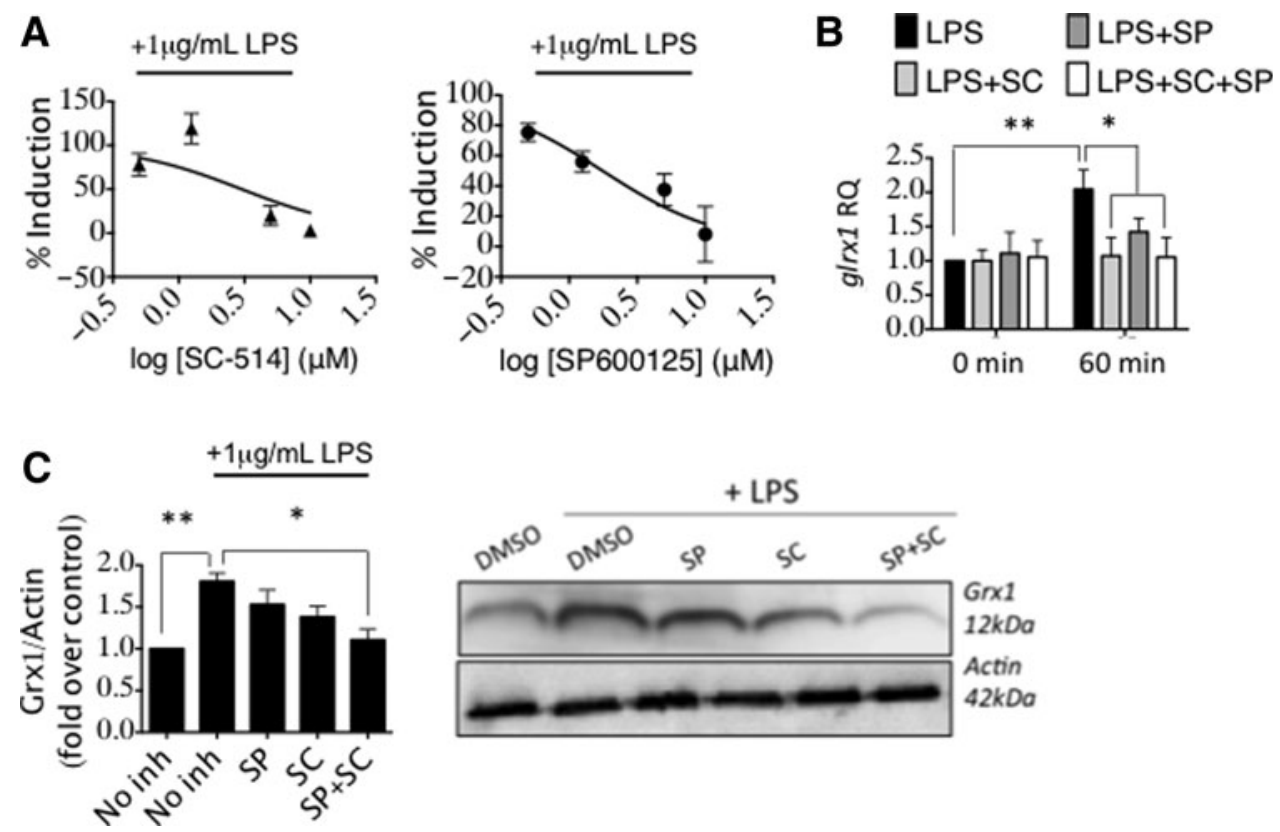

FIG. 6. glrx1 induction in microglia is mediated by AP-1 and NF-кB. (A) Grx1-specific activity in BV2 cells preincubated with IKK $\beta$ inhibitor (SC-514, $\boldsymbol{\Delta}$, left), or JNK inhibitor (SP600125, ๑, right), or vehicle alone (DMSO) for $1 \mathrm{~h}$, then stimulated with $1 \mu \mathrm{g} / \mathrm{ml}$ LPS in PBS, or vehicle alone (PBS) for $24 \mathrm{~h}$. Data bars represent Mean \pm SEM, $n=$ at least three independent samples, with at least two determinations of Grx1 activity. Data were converted to percent induction and then fit with a $\log$ (inhibitor) versus normalized response curve equation in each case. $R^{2}$ for $\mathrm{SC}=0.58, R^{2}$ for $\mathrm{SP}=0.55$. (B) $\mathrm{BV} 2$ cells were pretreated for $1 \mathrm{~h}$ with the respective kinase inhibitors alone $(0.5 \mu M$ each), or in combination, and then treated with $1 \mu \mathrm{g} / \mathrm{ml}$ LPS. .glrx $1 \mathrm{mRNA}$ levels were measured after $1 \mathrm{~h}$ LPS treatment. (C) BV2 cells were pretreated for $1 \mathrm{~h}$ with the respective kinase inhibitors alone $(0.5 \mu M$ each), or in combination, and then treated with $1 \mu \mathrm{g} / \mathrm{ml}$ LPS. Relative Grx 1 protein content was measured after $24 \mathrm{~h}$ LPS treatment. Variance was analyzed by one-way ANOVA with Dunnett's test for multiple comparisons relative to value for vehicle with LPS ("No inh+LPS") * $p<0.05$, ** $p<0.01$. Data bars represent Mean \pm SEM, $n=$ at least three independent samples, with at least two determinations of Grx 1 content. $* p<0.05$; $* * p<0.01$. JNK, c-Jun N-terminal kinase; NF- $\kappa \mathrm{B}$, nuclear factor kappa-light-chain-enhancer of activated B cells.

Grx1 knockout mice show decreased neuroinflammation at baseline and no TH loss on HFHS diet. To test the converse of Grx1 overexpression, we examined Grx1knockout mice. We found C57BL/6 $\mathrm{J}^{\mathrm{Grx} 1-/-}$ mice to express lower levels of tnfa and il6 mRNA compared to WT controls (Fig. 8D), suggesting that lack of Grx1 decreases basal neuroinflammation. TH levels in whole brain homogenates from C57BL/6J ${ }^{\text {Grx 1-/- }}$ mice maintained either on HFHS or control chow were not significantly altered compared to C57BL/ $6 \mathrm{~J}^{\mathrm{WT}}$ mice on control chow (Fig. 8E).

\section{Discussion}

\section{Glutaredoxin upregulation: a common factor} in proinflammatory activation of immune cells

Our current study revealed that LPS and TNF- $\alpha$ induce Grx1 in the BV2 mouse microglial cell line, and primary neonatal mouse microglia and primary human microglia respond to LPS in like manner (Figs. 2 and 3). Moreover, direct and selective upregulation of Grx1 by adenoviralmediated overexpression leads to activation of the model microglia and increased production of proinflammatory cytokines (Fig. 4), mimicking the effects of LPS. These findings provide first evidence for a regulatory role for Grx1 in proinflammatory activation of CNS immune cells, analogous to previous studies by us and others that have im- plicated Grx1 upregulation in mediating inflammatory activation of retinal glial (Mueller) cells (44) and alveolar macrophages (3). Thus, Grx1 induction and concomitant proinflammatory activation appear to be a common phenomenon across various types of immune cells throughout the body.

\section{Mechanism of microglial Grx1 induction and implications for $P D$}

Previously, Grx 1 induction in macrophages was shown to proceed through $\mathrm{NF}-\kappa \mathrm{B}(3)$. In the present study, we found a pathway of Grx1 induction that appears to be specific to the microglia (Fig. 9). Our data indicate that LPSstimulated induction of Grx1 in microglia is mediated through both the AP- 1 and $\mathrm{NF}-\kappa \mathrm{B}$ pathways, and $\mathrm{NF}-\kappa \mathrm{B}-$ p65-SSG is concomitantly deglutathionylated (Figs. 4 and $6)$. The involvement of both AP- 1 and $\mathrm{NF}-\kappa \mathrm{B}$ pathways mirrors LPS induction of known inflammatory proteins, such as TNF- $\alpha$, which has been documented to proceed via both pathways (7). Therefore, based on transcriptional control, our findings classify GLRX as a bona fide inflammatory gene in the microglia.

We also found that Nurr1 represses glrxl induction (Fig. 7). Nurr1 has attracted attention in the field of PD research due to its involvement in both neuronal survival and 
A
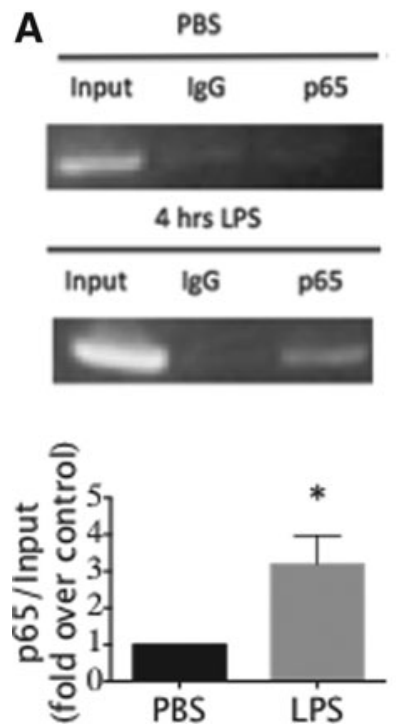

B
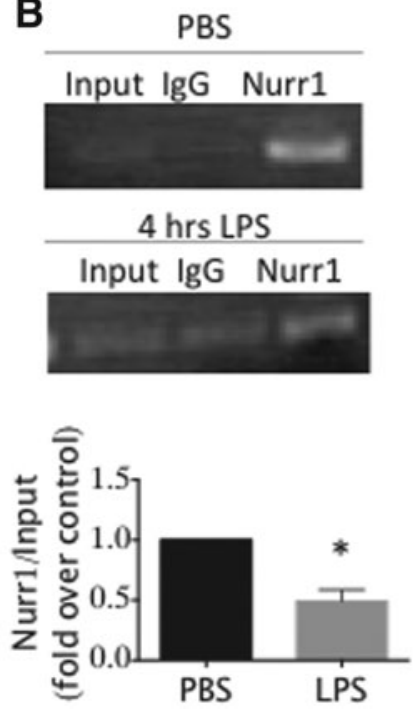

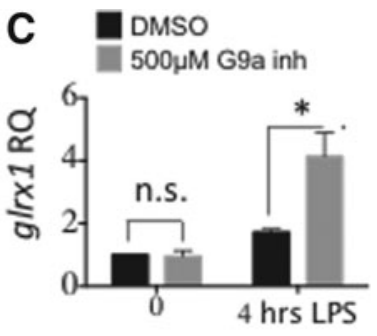

D

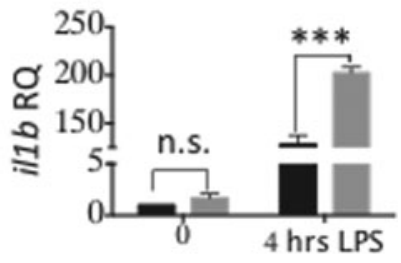

FIG. 7. glrxl induction by LPS is regulated by the NFKB/Nurr1 axis. BV2 cells were stimulated with $1 \mu \mathrm{g} / \mathrm{ml}$ LPS for $4 \mathrm{~h}$, then chromatin immunoprecipitation was carried out with primers for the putative NF- $\kappa \mathrm{B}$ binding site on the GLRX promoter and using antibodies for the p65 subunit of NF- $\kappa \mathrm{B}(\mathbf{A})$ or Nurr1 (B); densitometric quantification is shown in the corresponding bar graphs; ${ }^{*} p<0.05$. (C) Relative glrxl mRNA content in BV2 cells treated with $500 \mathrm{n} M$ of G9a inhibitor UNC0638 (Sigma) or DMSO for 48 h in 5\% fetal bovine serum DMEM. Cells were then treated with $1 \mu \mathrm{g} / \mathrm{ml} \mathrm{LPS} \mathrm{for} 4 \mathrm{~h}$ in serum-free DMEM. (D) illb mRNA content was measured as a positive control for inhibition of Nurr 1-mediated repression in cells treated as in (C). RQ, relative quantity normalized to gapdh mRNA. Data bars represent mean \pm SEM, $n=$ at least three independent samples, with four determinations of mRNA expression. ${ }^{*} p<0.05 ; * * * p<0.001$. DMEM, Dulbecco's Modified Eagle Medium; Nurr1, nuclear receptor related-1.

microglial inflammation, including a reported decrease in Nurr1+/TH+ neurons in postmortem samples from PD patients (12). Furthermore, Nurr1 appears to be required for proper development of DA neurons and for transcription of a number of proteins related to DA functioning, such as TH.

Recently, various Nurr1 agonists have been reported to ameliorate microglial activation, neurodegeneration, and behavioral defects in a number of animal models of PD (22, 47). As Nurr1/CoREST has been shown to govern expression of inflammatory genes in microglia (40), our findings point to regulation of Grx1 expression in the microglia as an inflammatory response, rather than an antioxidant response. Indeed, upregulation of Grx1 in BV2 model microglia led to cell death of model DA neurons in coculture (Fig. 5), suggesting a potential contribution of microglial Grx1 upregulation to PD development (vide infra).

\section{Interrelationship of Grx1 and TNF- $\alpha$ : role in inflammation}

We found Grx1 knockdown in BV2 microglial cells to correspond to a decrease of IL-6 release in response to LPS (Fig. 4), akin to what we observed previously for Mueller cells (44), suggesting that diminution of Grx1 may dampen microglial activation or shift microglia into an alternate activation state. We also found that Grx1-knockout mice $\left(\mathrm{C} 57 \mathrm{Bl} / 6 \mathrm{~J}^{\mathrm{Grx} 1-1-}\right)$ express lower levels of thfa and il6 compared to WT controls (Fig. 8E). Decreasing TNF- $\alpha$ and IL-6 levels has been shown to be beneficial in models of PD in vitro and in vivo $(24,29)$.

Akin to what has been demonstrated for lung inflammation (2) and the inflammation of diabetic retinopathy (44), our current data suggest that Grx1 may be a therapeutic target for decreasing neuroinflammation in PD. However, as Grx1 diminution in neurons has been shown to promote apoptosis (39), and diminution of Grx1 in DA neurons was observed in brain samples from PD patients relative to controls (18), it would be important to target therapeutic inhibition of Grx1 specifically to the inflammatory cells.

TNF- $\alpha$ is known as an important cytokine in PD (11), as well as in normal brain signaling [reviewed in (31)]. We found a positive correlation between TNF- $\alpha$ and Grx1 levels in healthy subjects, at both protein and transcript levels, for mouse midbrain and for human midbrain (Fig. 1). This relationship is consistent with the notion that Grx 1 may be a driver of neuroinflammation pertinent to PD. Since TNF- $\alpha$ induces upregulation of Grx1 in microglia (Fig. 3) and upregulation of microglial Grx1 promotes TNF- $\alpha$ production (Fig. 4) and neurotoxicity (Fig. 5), these in vitro studies taken together suggest that production of TNF- $\alpha$ in the brain might enhance neuroinflammation autocatalytically through induction of Grx1. Hence, our findings suggest that elevated Grx1 may predispose to development of PD via increasing TNF- $\alpha$ levels.

Remarkably, at the mRNA expression level, the Grx1TNF- $\alpha$ correlation appears to become inverted for samples of substantia nigra from PD patients (Fig. 1). Since most reports, including the current study, have identified Grx1 as a positive mediator of inflammation, this set of data for PD patients presents a previously unseen inverse relationship between glrxl and tnfa expression in the context of PD. A bell-shaped curve for TNF- $\alpha$ immunogenicity in macrophages has been reported (48), prompting us to hypothesize an analogous relationship for microglia. Accordingly, higher levels of TNF- $\alpha$, characteristic of PD (30), might lead to 

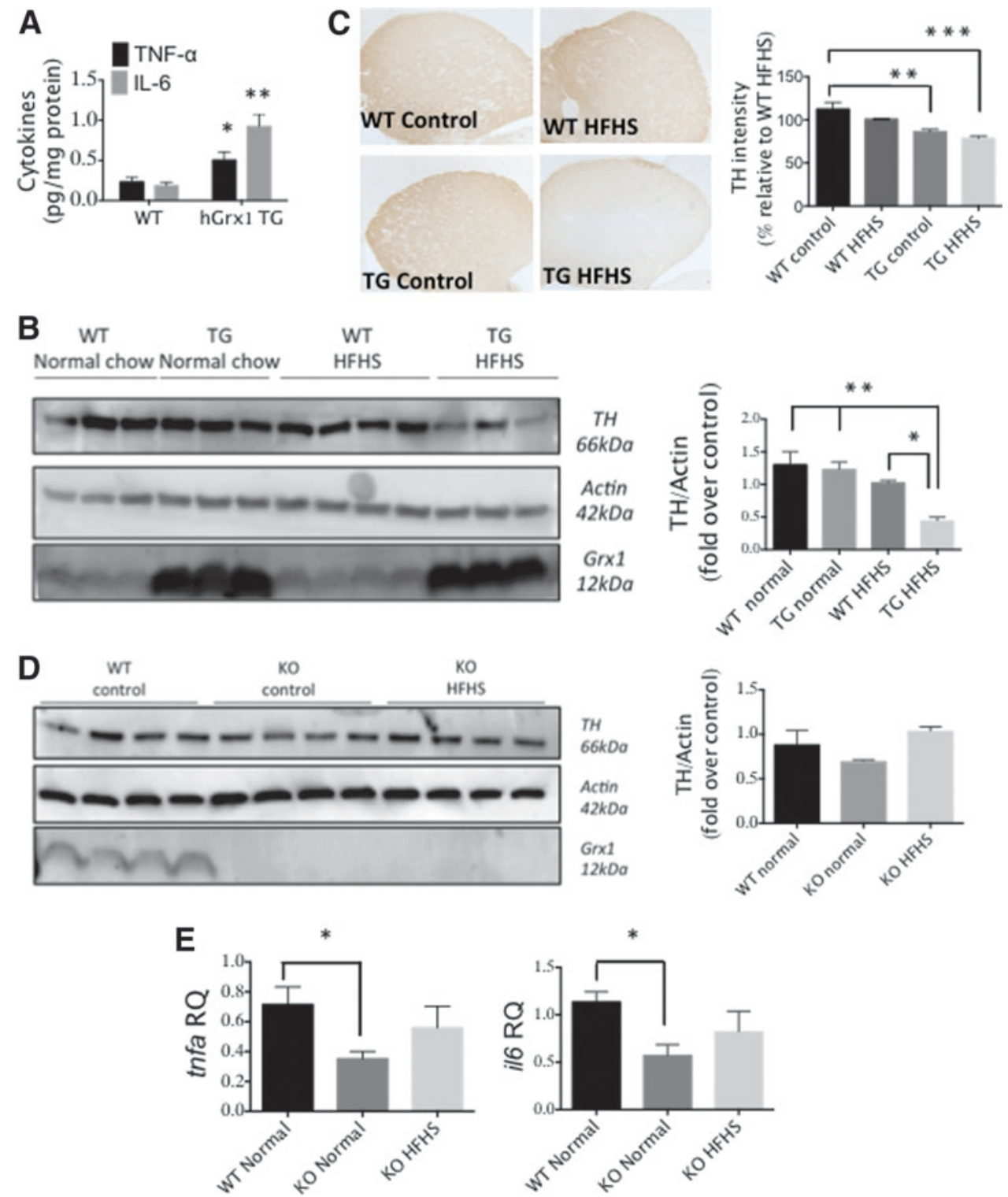

FIG. 8. C57BL/6J ${ }^{\text {hGrx1TG }}$ mice on HFHS diet display TH loss and degeneration of DA striatal axonal terminals. (A) TNF- $\alpha$ and IL-6 levels in whole brain homogenates from C57BL/6 $\mathrm{J}^{\mathrm{hGrx} 1 \mathrm{TG}}$ mice versus age- and sex-matched C57BL/6 $\mathrm{J}^{\mathrm{WT}}$ controls. $n=3 \pm$ SEM, with three technical replicates. (B) TH levels for whole-brain homogenates from 10-month-old male C57BL/6J ${ }^{\text {hGrx1TG }}$ or C57BL/6J mice fed a HFHS diet or normal chow for 8 months. Differences analyzed by one-way ANOVA compared to TG HFHS. ${ }^{*} p<0.05, * * p<0.01$. Data bars (right) represent mean \pm SEM, $n=3-4$ with two technical replicates for $(\mathbf{B})$. (C) TH immunostaining in striatum of C57BL/6 $\mathrm{J}^{\mathrm{hGrx} 1 \mathrm{TG}}$ and C57BL/6J ${ }^{\mathrm{WT}}$ mice fed HFHS diet or control chow. Quantification (data bars, right) was done as described in Materials and Methods section. $n=3-4 \pm$ SEM. $* p<0.05$, $* * p<0.01$ by one-way ANOVA compared to WT HFHS. (D) Representative Western blot and desitometric quantification of TH contents in brain homogenates of C57BL/6 $\mathrm{J}^{\mathrm{Grx} 1-/-}$ or C57BL/6 $6^{\mathrm{WT}}$ mice fed HFHS or normal chow. (E) tnfa and il6 mRNA levels in midbrains of mice described in (D). Differences analyzed by one-way ANOVA. $* p<0.05$. DA, dopaminergic; HFHS, high-fat high sugar; TH, tyrosine hydroxylase. To see this illustration in color, the reader is referred to the web version of this article at www.liebertpub.com/ars

decreased Grx1 levels, consistent with a decrease in Grx1 level observed in the substantia nigra of PD patients (18).

However, we did not observe a biphasic induction of glrx 1 mRNA when BV2 cells were treated with increasing concentrations of TNF- $\alpha$ (Fig. 3D), so other alternatives must be considered. For example, effects of TNF- $\alpha$ levels on neurons (8) and microglia (and/or astrocytes) may be opposing and thereby contribute to a perturbation of the glrxl-tnfa relationship as PD advances. Aged microglia have been found to display prolonged activation (17). If such prolonged activation occurred in $\mathrm{PD}$, it might explain the observed reversal of the glrx1-tnfa relationship. Thus, Grx1 might become stabilized at the protein level, leading to an apparent relative decrease in the glrx $1 \mathrm{mRNA}$, while driving increased tnfa transcription through NF- $\kappa \mathrm{B}$ activation. Clearly, additional studies are warranted to characterize the relationship between TNF- $\alpha$ and Grx 1 levels as a function of PD disease progression. 

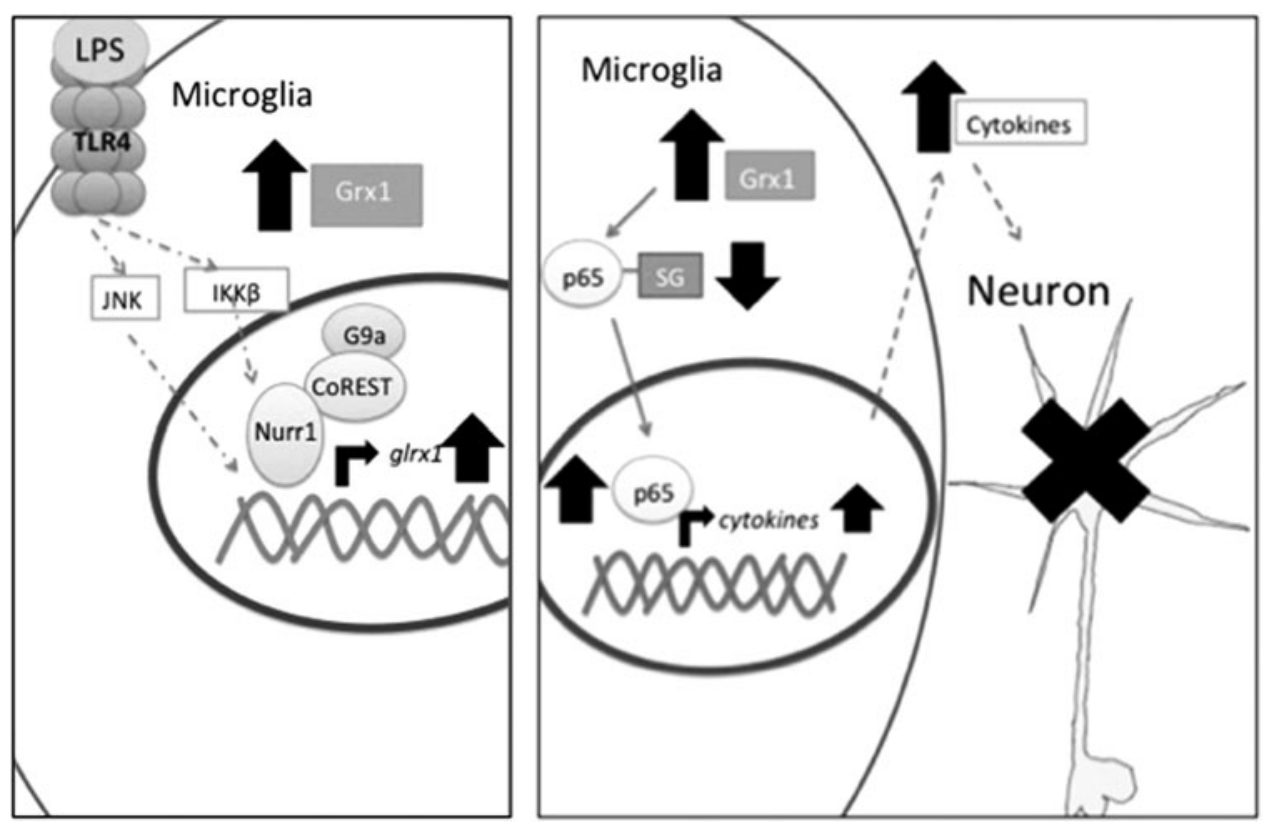

FIG. 9. Schematic Representation of Grx1 transcriptional induction and subsequent neurotoxicity. In this simplified schematic, TLR4 ligand, either exogenous (LPS) or endogenous (e.g., HMGB1), activates microglia. This leads to activation of AP-1 and NF- $\kappa$ B signaling pathways. Nurr1, in complex with CoREST and G9a, among others, occupies the upstream region of the GLRX gene. Upon binding of the p65 subunit of NF- $\kappa \mathrm{B}$, Nurr1 complex is cleared from the promoter region, allowing for glrx 1 mRNA transcription. AP-1 induces glrxl likely independently of Nurr1. Following Grx 1 induction and subsequent decrease in glutathionylated intracellular proteins, cytokine release from the microglia is increased through an unknown mechanism, likely through an increase in synthesis. Increased cytokine release likely drives apoptosis of neighboring neurons.

\section{Exacerbating effect of insulin resistance on DA viability}

Metabolic syndrome has been identified as a risk factor of PD in humans (56), and mice with diet-induced insulin resistance have been found to be more susceptible to DA neuronal loss from treatment with MPTP $(5,9)$ or 6-OHDA (32), which promote neuroinflammation besides their direct neurotoxic effects. Accordingly, we hypothesized that microglial activation driven by Grx1 upregulation would synergize with HFHS diet-induced inflammation to promote neuronal degeneration.

Indeed, we found that $\mathrm{C} 57 \mathrm{BL} / 6 \mathrm{~J}^{\mathrm{hGrx} 1 \mathrm{TG}}$ mice display increased neuroinflammation and show a loss of DA striatal axonal terminals when maintained on HFHS diet (Fig. 8C), indicating that the observed decrease in $\mathrm{TH}$ protein levels (Fig. 8B) likely occurs due to loss of DA striatal axon terminals. It is postulated that DA neuronal loss characteristic of PD begins in the axons in a process termed "dying-back degeneration" [reviewed in (6)]. The role of inflammatory cells in this process is poorly understood; however, changes in striatal axonal morphology indicative of damage have been correlated with increased microglial activation in a rat model of alpha-synucleinopathy (10). This suggests that microglial activation, possibly phagocytosis, may be driving neuronal damage, but the precise relationship is unclear. Overall, our results suggest that neuroinflammation driven by Grx1 overexpression may synergize with other insults, such as insulin resistance, to induce significant loss of $\mathrm{TH}$ neurons and promote or worsen PD.

In this regard, HMGB1, an endogenous TLR4 ligand, has been found to be elevated in the plasma of diabetic patients
(52). It is conceivable that, in the mice on the HFHS diet and in some human patients, increased HMGB1 may activate TLR4 in the microglia and promote Grx1 upregulation and subsequent neurotoxic inflammation. Recently, the drug pioglitazone, which is known to reduce insulin resistance, has garnered attention as a potential disease-modifying agent in PD. Pioglitazone displays efficacy in in vivo and in vitro models of PD (4), suggesting coincident treatment targets in diabetes and PD.

Our study is the first to report a potential deleterious role of Grx1 overexpression in PD. A number of studies have demonstrated protective effects of elevated neuronal Grx1 in the context of PD models (13), and the occurrence of somewhat higher Grx1 levels in female Swiss albino mice was reported to be protective against chemically induced neurodegeneration in vivo (21). We postulate that, in the case of general Grx1 overexpression in the brain, deleterious effects of Grx1-driven microglial inflammation overwhelm protective effects of Grx1 overexpression in the neurons, resulting in neuronal apoptosis. Further studies on the effect of Grx1 overexpression in PD models in vivo, preferably with cellselective overexpression of Grx1, are necessary to fully understand the role of Grx1 elevation in PD pathogenesis.

The C57BL/6J ${ }^{\text {hGrx1TG }}$, C57BL/6J ${ }^{\text {Grx1-/- }}$, and C57BL/6J ${ }^{\mathrm{WT}}$ mice used for our HFHS studies were bred to deliberately express the mutated $N n t^{C 57 B L / 6}$ (nicotinamide nucleotide transhydrogenase) allele, which increases their susceptibility to metabolic disease $(14,49)$. As Nnt impairment has been shown to weaken redox functioning $(27,38)$, it is conceivable that the role of Grx1 in DA neuronal homeostasis could be altered in these mice. It will be important in future studies to 
discern the role of Grx1 in DA neuronal homeostasis in nonNnt mutant mice. Finally, microglia have been interpreted to be the primary driver of inflammation in the brain; however, the potential inflammatory effects of astrocyte activation should not be overlooked in this context.

\section{Genetic evidence for elevated Grx1 in PD onset}

Increased copy number of genes, such as alpha-synuclein (46), has been associated with increased risk of PD development. Here we have reported that increased GLRX gene copy number corresponded with earlier age of PD onset (Fig. 1), providing the first evidence for increased GLRX possibly promoting PD progression. No significant differences in disease severity markers CSF alpha-synuclein and total tau were observed for this same cohort of patient samples (data not shown), suggesting that Grx1 overexpression may influence PD onset, but not severity. Reflecting on our mouse data where upregulation of Grx 1 is linked to increased cytokine production, we interpret the data for increased human GLRX copy number to indicate that increased inflammation due to increased expression of Grx 1 promotes earlier PD onset. However, the relatively small size of our sample prevents us from drawing a definitive conclusion regarding the impact of GLRX copy number on PD development. Additional studies with a larger sample size are needed to validate our findings and further investigate the genetic relationship between Grx1 and PD.

In summary, we have found that Grx1 is elevated in microglia following stimulation by LPS or TNF- $\alpha$. The Grx 1 induction enhances microglial activation and promotes cell death of cocultured model neurons, consistent with a neurotoxic effect of elevated Grx1 levels in microglia. We found C57BL/6J ${ }^{\text {hGrx1TG }}$ mice on a HFHS diet exhibit diminished brain $\mathrm{TH}$, highlighting the potential deleterious effect of increased Grx 1 content on DA neuronal survival. Furthermore, we found that increased GLRX copy number in human PD patients was associated with earlier disease onset, thereby identifying Grx1 overexpression as a potential PD susceptibility factor. We expect our current findings to stimulate further studies on the role of Grx1 in PD, including distinguishing the relative roles of Grx 1 in neuroprotection versus neuroinflammation, and the relative merits of upregulation versus development of specific inhibitors of Grx1 as novel therapeutic approaches to PD.

\section{Materials and Methods}

\section{Reagents}

NADPH and TNF- $\alpha$ were purchased from Roche. Cysteinyl glutathione disulfide (CSSG) was purchased from Toronto Research Chemicals. Anti-Grx1 antibody was custom generated by Genscript. Anti-GSH antibody was purchased from Millipore. Anti-PARP (ab6079) and anti-TH (ab112) antibodies were purchased from Abcam. Antibodies against p65 (C-20) and $\mathrm{I} \kappa \mathrm{B} \alpha(\mathrm{C}-21)$ were purchased from Santa Cruz. Enhanced chemical fluorescence (ECF) substrate was purchased from Thermo Fisher. TRIzol, DDAO-phosphate, random hexamers, TaqMan Fast Universal PCR Master Mix, dNTPs, first strand buffer, dithiothreitol (DTT), and RNase OUT were purchased from Life Technologies. All secondary antibodies, antibody to $\beta$-actin, LPS (0111:B4 strain), and all other chemicals were purchased from Sigma-Aldrich.

\section{Animals and animal tissue}

C57BL/6J mice were purchased from Jackson Laboratories. Unless indicated otherwise, mice were housed at the CWRU animal facility on a 12-h light/12-h dark cycle with ad libitum access to food and water. All experimental procedures were approved by the IACUC review board and done in accordance with all vertebrate animal care regulations. Male C57BL/6J ${ }^{\mathrm{hGrx} 1 \mathrm{TG}}$ (33), C57BL/6J ${ }^{\mathrm{Grx} 1-1-}$, and matched $\mathrm{C} 57 \mathrm{BL} / 6 \mathrm{~J}^{\mathrm{WT}}$ mice, bred to deliberately express mutant form of $N n t$, were fed for 8 or 10 months, starting at 3 months of age, on a HFHS diet, previously characterized to induce metabolic syndrome $(36,54)$. These mice were housed at the Boston University animal care facility according to an IUCAC-approved protocol.

\section{Immunohistochemistry}

For analysis of $\mathrm{TH}$ levels in the striatum, mouse brains were collected at time of sacrifice and fixed in $4 \%$ formaldehyde. After fixation, brains were bisected coronally, embedded in paraffin, and sectioned. Immunohistochemistry was performed as previously described (18). Sections from all mice were immunostained at the same time. Images of the striatum from multiple levels were taken under identical conditions and analyzed blindly for staining intensity using Axiovision software (Zeiss). Relative TH staining intensity of the striatum was measured with the background cortical value subtracted from each section. At least four separate coronal sections were measured per animal, and the mean $\mathrm{TH}$ staining level was determined.

\section{Isolation of mouse primary neonatal microglia}

Primary microglia were isolated from p1-p4 pups as described elsewhere (28). Briefly, brains were triturated and plated in modified DMEM/F12 medium. After 17-20 days in culture, microglia and astrocytes were separated by trypsinization and microglia were plated into six-well plates at $\sim 8 \times 10^{5}$ cells/well and serum starved for at least $18 \mathrm{~h}$ before treatment; all treatments were in the absence of serum. Microglial purity was confirmed by morphology.

\section{Isolation of rat primary embryonic neurons}

Rat Primary embryonic neurons were isolated according to an established protocol (53). Coculture with BV2 microglia was started at neuronal days in vitro 7 .

\section{Cell lines and treatments}

BV2 immortalized murine microglia cells were a kind gift from Dr. Gary Landreth (CWRU Department of Neurosciences). SH-SY5Y human neuroblastoma cells were obtained from ATCC (Manassas, VA). BV2 cells were maintained in low-glucose $(5 \mathrm{~m} M)$ DMEM supplemented with $5 \%$ fetal bovine serum (FBS). BV2 cells were plated at $\sim 1 \times 10^{6}$ cells in $100 \mathrm{~mm}$ dishes or $\sim 1-3 \times 10^{5}$ cells/well in six-well dishes, depending on the particular experiment. Cells were plated in serum-free DMEM and allowed to adhere at least $3 \mathrm{~h}$ before beginning experiments. All BV2 experiments 
were carried out in serum-free DMEM. BV2 cells were not used past passage 30. SH-SY5Y cells were maintained in OptiMEM supplemented with 10\% FBS. SH-SY5Y cells were plated at $\sim 5 \times 10^{5}$ cells/well in six-well plates.

Primary human microglia were obtained from ScienCell. Each vial of cells was split evenly between two wells of a sixwell plate and plated and treated according to the manufacturer's instructions.

For kinase inhibition, BV2 cells were incubated with SC514 (IKK $\beta$ inhibitor, Sigma-Aldrich) and SP600125 (JNK inhibitor; Sigma-Aldrich) for $1 \mathrm{~h}$ in serum-free DMEM before LPS stimulation. For G9a inhibitor experiments, BV2 cells were plated at $\sim 1 \times 10^{5}$ cells/well in six-well plate in DMEM supplemented with 5\% FBS, cultured in the presence of $500 \mathrm{n} M$ UNC0638 (Sigma-Aldrich) for $48 \mathrm{~h}$, and stimulated with $1 \mu \mathrm{g} / \mathrm{ml}$ LPS in serum-free media for $4 \mathrm{~h}$. Cells were collected with TRIzol and processed for RT-PCR as described below.

\section{RNA silencing in BV2 cells}

BV2 cells were plated at $2 \times 10^{6}$ cells/well in six-well plate and left to adhere overnight in serum-free DMEM. Cells were then treated with $200 \mathrm{n} M$ final concentration of anti-GLRX1 siRNA (GE Dharmacon) or scrambled siRNA using oligofectamine (Thermo Fisher) $(4 \mu \mathrm{l} /$ well) for $24 \mathrm{~h}$ according to the manufacturer's instructions. Cells were then stimulated with $1 \mu \mathrm{g} / \mathrm{ml}$ LPS for $24 \mathrm{~h}$, and cell media collected and analyzed for cytokine content using ELISA.

\section{Adenoviral Grx1 overexpression}

Glutaredoxin-expressing adenovirus was obtained and utilized as described previously (45). BV2 cells were incubated with virus-containing serum-free DMEM for $2 \mathrm{~h}$ at $37^{\circ} \mathrm{C}$. The medium was removed, and cells were allowed to recover for $24 \mathrm{~h}$. Medium and cell lysates were collected separately for ELISA and immunoblotting.

\section{Coculture}

BV2 cells were seeded at $\sim 4 \times 10^{5}$ cells/insert onto nylon mesh inserts with a pore diameter of $0.4 \mu \mathrm{m}$ (Corning) and left to adhere in serum-free DMEM overnight. SH-SY5Y cells were plated at $\sim 5 \times 10^{5}$ cells/well in six-well plates and left to adhere overnight in Opti-MEM supplemented with $10 \%$ FBS. The next day, BV2 cells were stimulated with $1 \mu \mathrm{g} / \mathrm{ml}$ LPS or infected with adenovirus containing the GLRX1 gene or empty virus. SH-SY5Y cells treated with $1 \mu \mathrm{g} / \mathrm{ml}$ LPS in the absence of BV2 were used as a control for nonspecific LPS effect. SH-SY5Y cells were stimulated with $1 \mu M$ staurosporine for $4 \mathrm{~h}$ as a positive control for cell death.

Inserts containing treated BV2 cells were added to plates containing SH-SY5Y cells, and the coculture was incubated for $48 \mathrm{~h}$. SH-SY5Y cells were collected and immunoblotted for cleaved PARP, or stained with Hoechst 33342 dye (Invitrogen) to detect apoptotic nuclei (condensed chromatin), as previously described (39). To confirm Grx1 upregulation, the BV2 cells were lysed and processed for assay of Grx1 activity or for determination of Grx1 protein content by Western blotting.

\section{Brain tissue homogenization and analysis}

Whole mouse brains or midbrain samples were homogenized in lysis solution $\left(10 \mathrm{~m} M \mathrm{KH}_{2} \mathrm{PO}_{4}, 0.1 \%\right.$ Triton-X) supplemented with protease inhibitors (Sigma-Aldrich) at $3 \mathrm{ml}$ of lysis buffer per $1 \mathrm{~g}$ tissue and then allowed to lyse on ice for $20 \mathrm{~min}$. Homogenates were cleared by centrifugation at $15,000 \mathrm{rpm}$ at $4^{\circ} \mathrm{C}$ for $20 \mathrm{~min}$. Aliquots corresponding to $100 \mu \mathrm{g}$ protein were analyzed for TNF- $\alpha$ and IL- 6 content using an ELISA kit (BioLegend), according to the manufacturer's instructions. Brain homogenates from C57BL/ $6 \mathrm{~J}^{\mathrm{hGrx} 1 \mathrm{TG}}$ mice were lysed in the presence of $50 \mathrm{~m} M$ iodoacetamide and used in ELISAs for cytokines. Values were normalized to protein concentration and expressed as pg cytokine per $\mathrm{mg}$ of brain protein.

\section{Chromatin immunoprecipitation}

Confluent BV2 cells in $150 \mathrm{~mm}$ plates were stimulated with LPS for specific amounts of time. Cells were trypsinized, resuspended in serum-free DMEM, and cross-linked with formaldehyde. Nuclei were isolated, cooled in an icebath, and sheared using a QSonica ultrasonic liquid processor (30\% maximum amplitude, $10 \mathrm{~s}$ on, $30 \mathrm{~s}$ off, five pulses). Sheared chromatin divided into separate aliquots was incubated at $4{ }^{\circ} \mathrm{C}$ with antibodies either to p65 (C-20, $\left.20 \mu \mathrm{g}\right)$ or to Nurr1 (N-20, $20 \mu \mathrm{g}$ ), each conjugated to magnetic protein $\mathrm{G}$ beads (Dynabeads; Invitrogen). Beads were washed, bound chromatin was eluted, and crosslinking was reversed by incubation with $0.2 \mu \mathrm{g} / \mu$ l Proteinase K (Sigma-Aldrich).

Primers to the NF- $\kappa \mathrm{B}$ binding sequences of the GLRX promoter (3) were used for PCR. Isotypic IgG was used as control for nonspecific binding. PCR settings were as follows: (i) $95^{\circ} \mathrm{C}, 5 \mathrm{~min}$; (ii) $95^{\circ} \mathrm{C}, 30 \mathrm{~s}$; (iii) $52^{\circ} \mathrm{C}, 30 \mathrm{~s}$; (iv) $72^{\circ} \mathrm{C}, 30 \mathrm{~s}$ (repeat steps ii-iv, 34 times); and (5) $72^{\circ} \mathrm{C}, 5 \mathrm{~min}$. The expected PCR product is $\sim 250 \mathrm{~kb}$ in length, as observed. Band intensities were quantified using ImageJ.

\section{Glutaredoxin activity assay}

Spectrophotometric assay for Grx1 activity was performed as previously described (15), using cysteinyl glutathione disulfide as a substrate. One unit of Grx 1 activity corresponds to formation of $1 \mu \mathrm{mol}$ of GSSG product per minute.

\section{ELISA}

Levels of IL- 6 and TNF- $\alpha$ in culture medium were analyzed using ELISA kits from BioLegend, according to the manufacturer's instructions. Multiplex ELISA was performed using the BioRad multiplex murine cytokine Grp panel I kit, according to the manufacturer's instructions. Assays were performed on the BioPlex 200 system.

\section{Determination of glutathionylated protein content}

Glutathionylated protein content was measured as previously described (3).

\section{$R T-q P C R$}

Samples were solubilized in TRIzol, and mRNA was extracted according to the manufacturer's instructions. mRNA was transcribed into cDNA using SuperScript II (Thermo Fisher). Commercially available TaqMan probes were used 
for glrx1 (Mm00728386_s1), il6 (Mm00434228_m1), and tnfa (Mm00443258_m1) (Life Technologies); gapdh (Mm99999915_g1) was used as an internal control. Assays were performed on the ABI StepOnePlus machine using standard settings, and ABI StepOne Software v2.0 was used to generate results.

\section{Immunoprecipitation}

BV2 cells were lysed in lysis buffer $\left(10 \mathrm{~m} M \mathrm{KH}_{2} \mathrm{PO}_{4}\right.$, $0.1 \%$ Triton-X) containing $50 \mathrm{~m} M$ iodoacetamide to block free thiol groups and preserve glutathionylation. p65 was immunoprecipitated using the C-20 antibody against p65 (Santa Cruz) linked to Protein G beads (Invitrogen). After elution, Western blot analysis was carried out under nonreducing conditions, and immunoreactivity with both anti-GSH antibody and separately with anti-p65 antibody was used to identify glutathionylated p65.

\section{Western blotting}

Samples were lysed in lysis buffer (above), and protein concentration was determined using the Pierce BCA Protein Assay kit (Thermo Scientific), according to the manufacturer's protocol. Twenty to $50 \mu \mathrm{g}$ of cell protein was solubilized in loading buffer, reduced with $1 \mu \mathrm{l}$ of 1M DTT (unless under nonreducing conditions), boiled at $95^{\circ} \mathrm{C}$, and alkylated with $3 \mu \mathrm{l}$ of $1 \mathrm{M}$ iodoacetamide. Samples were separated on a $15 \%$ bisacrylamide gel and transferred onto a polyvinylidene fluoride membrane. Membranes were blocked in 5\% nonfat dry milk in Tris-buffered saline $0.05 \%$ Tween- 20 and then incubated with primary antibodies overnight at $4^{\circ} \mathrm{C}$. Membranes were incubated with alkaline phosphatase-linked secondary antibodies, then developed with ECF or DDAO-phosphate, and visualized with the STORM or Typhoon imagers (General Electric). Band intensity was quantified using ImageQuant software.

\section{Gene expression analysis}

mRNA expression data from postmortem samples of substantia nigra from PD patients $(n=11)$ and matched controls $(n=15)$ [accession number GSE20295, first published in Zhang et al. (57)] were obtained from the Gene Expression Omnibus database (www.ncbi.nlm.nih.gov/geo/). Data from the remaining subjects were analyzed for differential expression using GEO2R (www.ncbi.nlm.nih.gov/geo/geo2r). For genes with multiple probes, average values were used.

\section{Copy number variant analysis}

Whole exome sequence data for 646 PD patients captured using Illumina Nextera Rapid Capture Expanded Exome kit were obtained from Parkinson's Progressive Marker Initiative. Sequencing reads mapping to chromosome 5 were extracted from the whole exome data. The reads from these samples were used to generate background coverage and GC content. Data were analyzed for copy number variants (CNVs) using exomeCopy (www.bioconductor.org/ packages/2.9/bioc/html/exomeCopy.html), which has been shown to have the most accuracy when detecting shorter CNVs (42). The resulting copy number predictions were filtered to only those with a copy number prediction greater than or less than two, overlapping the GLRX gene. PD pa- tients were grouped by copy number, and disease parameters were analyzed as described in figure legends.

\section{Statistical analysis}

Statistical significance of differences between mean values was assessed via two-tailed unpaired Student's $t$-test with Welch's correction or one-way ANOVA with Dunnett's test for multiple comparisons using GraphPad Prism v6.0. $p$-Values less than 0.05 were considered significantly different.

\section{Acknowledgments}

The authors thank Clinton J. Miller for invaluable assistance with genomic data analysis and Drs. Gary Landreth, George Dubyak, Amy Wilson-Delfosse, Marvin Nieman, and Vijayalakshmi Ravindranath for critical review of the article. Data used in the preparation of this article were obtained from the Parkinson's Progression Markers Initiative (PPMI) database (www.ppmi-info.org/data). PPMI-a public-private partnership - is funded by the Michael J. Fox Foundation for Parkinson's Research and funding partners, including Abbvie, Avid Radiopharmaceuticals, Bristol-Myers Squibb, Covance, GE Healthcare, Genentech, GlaxoSmithKline, Eli Lilly, Lundbeck, Merck, Meso Scale Discovery, Pfizer, Piramal, Roche, Servier, and UCB.

This work was supported by NIH R21 grant NS085503 (J.J.M.), Department of Veterans Affairs Merit Review grant BX000290 (J.J.M.), NIH R01 grants DK103750 (M.M.B.) and HL133013 (R.M.), NIH institutional training grant T32 NS077888 (S.J.), along with institutional support from CWRU.

\section{Author Disclosure Statement}

No competing financial interests exist.

\section{References}

1. Adluri RS, Thirunavukkarasu M, Zhan L, Dunna NR, Akita Y, Selvaraju V, Otani H, Sanchez JA, Ho YS, and Maulik N. Glutaredoxin-1 overexpression enhances neovascularization and diminishes ventricular remodeling in chronic myocardial infarction. PLoS One 7: e34790, 2012.

2. Aesif SW, Anathy V, Kuipers I, Guala AS, Reiss JN, Ho YS, and Janssen-Heininger YM. Ablation of glutaredoxin-1 attenuates lipopolysaccharide-induced lung inflammation and alveolar macrophage activation. Am J Respir Cell Mol Biol 44: 491-499, 2011.

3. Aesif SW, Kuipers I, van der Velden J, Tully JE, Guala AS, Anathy V, Sheely JI, Reynaert NL, Wouters EF, van der Vliet A, and Janssen-Heininger YM. Activation of the glutaredoxin-1 gene by nuclear factor kappaB enhances signaling. Free Radic Biol Med 51: 1249-1257, 2011.

4. Aviles-Olmos I, Limousin P, Lees A, and Foltynie T. Parkinson's disease, insulin resistance and novel agents of neuroprotection. Brain 136: 374-384, 2013.

5. Bousquet M, St-Amour I, Vandal M, Julien P, Cicchetti F, and Calon F. High-fat diet exacerbates MPTP-induced dopaminergic degeneration in mice. Neurobiol Dis 45: 529-538, 2012.

6. Burke RE and O'Malley K. Axon degeneration in Parkinson's disease. Exp Neurol 246: 72-83, 2013.

7. Chen H, Wang F, Mao H, and Yan X. Degraded lambdacarrageenan activates NF-kappaB and AP-1 pathways in 
macrophages and enhances LPS-induced TNF-alpha secretion through AP-1. Biochim Biophys Acta 1840: 2162 2170, 2014.

8. Chertoff M, Di Paolo N, Schoeneberg A, Depino A, Ferrari C, Wurst W, Pfizenmaier K, Eisel U, and Pitossi F. Neuroprotective and neurodegenerative effects of the chronic expression of tumor necrosis factor alpha in the nigrostriatal dopaminergic circuit of adult mice. Exp Neurol 227: 237-251, 2011.

9. Choi JY, Jang EH, Park CS, and Kang JH. Enhanced susceptibility to 1-methyl-4-phenyl-1,2,3,6-tetrahydropyridine neurotoxicity in high-fat diet-induced obesity. Free Radic Biol Med 38: 806-816, 2005.

10. Chung CY, Koprich JB, Siddiqi H, and Isacson O. Dynamic changes in presynaptic and axonal transport proteins combined with striatal neuroinflammation precede dopaminergic neuronal loss in a rat model of AAV alphasynucleinopathy. J Neurosci 29: 3365-3373, 2009.

11. De Lella Ezcurra AL, Chertoff M, Ferrari C, Graciarena M, and Pitossi F. Chronic expression of low levels of tumor necrosis factor-alpha in the substantia nigra elicits progressive neurodegeneration, delayed motor symptoms and microglia/macrophage activation. Neurobiol Dis 37: 630 640, 2010.

12. Decressac M, Volakakis N, Bjorklund A, and Perlmann T. NURR1 in Parkinson disease-from pathogenesis to therapeutic potential. Nat Rev Neurol 9: 629-636, 2013.

13. Durgadoss L, Nidadavolu P, Valli RK, Saeed U, Mishra M, Seth P, and Ravindranath V. Redox modification of Akt mediated by the dopaminergic neurotoxin MPTP, in mouse midbrain, leads to down-regulation of pAkt. FASEB $J$ 26: 1473-1483, 2012.

14. Freeman HC, Hugill A, Dear NT, Ashcroft FM, and Cox RD. Deletion of nicotinamide nucleotide transhydrogenase: a new quantitive trait locus accounting for glucose intolerance in C57BL/6J mice. Diabetes 55: 2153-2156, 2006.

15. Gallogly MM, Starke DW, Leonberg AK, Ospina SM, and Mieyal JJ. Kinetic and mechanistic characterization and versatile catalytic properties of mammalian glutaredoxin 2: implications for intracellular roles. Biochemistry 47: 11144-11157, 2008.

16. Gorelenkova Miller O and Mieyal JJ. Sulfhydryl-mediated redox signaling in inflammation: role in neurodegenerative diseases. Arch Toxicol 89: 1439-1467, 2015.

17. Harry GJ. Microglia during development and aging. Pharmacol Ther 139: 313-326, 2013.

18. Johnson WM, Yao C, Siedlak SL, Wang W, Zhu X, Caldwell GA, Wilson-Delfosse AL, Mieyal JJ, and Chen SG. Glutaredoxin deficiency exacerbates neurodegeneration in C. elegans models of Parkinson's disease. Hum Mol Genet 24: 1322-1335, 2015.

19. Kawai T and Akira S. Signaling to NF-kappaB by Toll-like receptors. Trends Mol Med 13: 460-469, 2007.

20. Keane KN, Cruzat VF, Carlessi R, de Bittencourt PI, Jr., and Newsholme P. Molecular events linking oxidative stress and inflammation to insulin resistance and beta-cell dysfunction. Oxid Med Cell Longev 2015: 181643, 2015.

21. Kenchappa RS, Diwakar L, Annepu J, and Ravindranath V. Estrogen and neuroprotection: higher constitutive expression of glutaredoxin in female mice offers protection against MPTP-mediated neurodegeneration. FASEB $J$ 18: 1102-1104, 2004.

22. Kim CH, Han BS, Moon J, Kim DJ, Shin J, Rajan S, Nguyen QT, Sohn M, Kim WG, Han M, Jeong I, Kim KS,
Lee EH, Tu Y, Naffin-Olivos JL, Park CH, Ringe D, Yoon HS, Petsko GA, and Kim KS. Nuclear receptor Nurr1 agonists enhance its dual functions and improve behavioral deficits in an animal model of Parkinson's disease. Proc Natl Acad Sci U S A 112: 8756-8761, 2015.

23. Kowal SL, Dall TM, Chakrabarti R, Storm MV, and Jain A. The current and projected economic burden of Parkinson's disease in the United States. Mov Disord 28: 311-318, 2013.

24. Li XZ, Bai LM, Yang YP, Luo WF, Hu WD, Chen JP, Mao CJ, and Liu CF. Effects of IL-6 secreted from astrocytes on the survival of dopaminergic neurons in lipopolysaccharideinduced inflammation. Neurosci Res 65: 252-258, 2009.

25. Liao BC, Hsieh CW, Lin YC, and Wung BS. The glutaredoxin/glutathione system modulates NF-kappaB activity by glutathionylation of p65 in cinnamaldehyde-treated endothelial cells. Toxicol Sci 116: 151-163, 2010.

26. Lin YC, Huang GD, Hsieh CW, and Wung BS. The glutathionylation of p65 modulates NF-kappaB activity in 15deoxy-Delta(1)(2),(1)(4)-prostaglandin J(2)-treated endothelial cells. Free Radic Biol Med 52: 1844-1853, 2012.

27. Lopert $\mathrm{P}$ and Patel M. Nicotinamide nucleotide transhydrogenase (Nnt) links the substrate requirement in brain mitochondria for hydrogen peroxide removal to the thioredoxin/peroxiredoxin (Trx/Prx) system. J Biol Chem 289: 15611-15620, 2014.

28. Mandrekar-Colucci S, Karlo JC, and Landreth GE. Mechanisms underlying the rapid peroxisome proliferatoractivated receptor-gamma-mediated amyloid clearance and reversal of cognitive deficits in a murine model of Alzheimer's disease. J Neurosci 32: 10117-10128, 2012.

29. McCoy MK, Martinez TN, Ruhn KA, Szymkowski DE, Smith CG, Botterman BR, Tansey KE, and Tansey MG. Blocking soluble tumor necrosis factor signaling with dominant-negative tumor necrosis factor inhibitor attenuates loss of dopaminergic neurons in models of Parkinson's disease. J Neurosci 26: 9365-9375, 2006.

30. Mogi M, Harada M, Riederer P, Narabayashi H, Fujita K, and Nagatsu T. Tumor necrosis factor-alpha (TNF-alpha) increases both in the brain and in the cerebrospinal fluid from parkinsonian patients. Neurosci Lett 165: 208-210, 1994.

31. Montgomery SL and Bowers WJ. Tumor necrosis factoralpha and the roles it plays in homeostatic and degenerative processes within the central nervous system. J Neuroimmune Pharmacol 7: 42-59, 2012.

32. Morris JK, Bomhoff GL, Stanford JA, and Geiger PC. Neurodegeneration in an animal model of Parkinson's disease is exacerbated by a high-fat diet. Am J Physiol Regul Integr Comp Physiol 299: R1082-R1090, 2010.

33. Murdoch CE, Shuler M, Haeussler DJ, Kikuchi R, Bearelly P, Han J, Watanabe Y, Fuster JJ, Walsh K, Ho YS, Bachschmid MM, Cohen RA, and Matsui R. Glutaredoxin1 up-regulation induces soluble vascular endothelial growth factor receptor 1, attenuating post-ischemia limb revascularization. J Biol Chem 289: 8633-8644, 2014.

34. Okuda M, Inoue N, Azumi H, Seno T, Sumi Y, Hirata K, Kawashima S, Hayashi Y, Itoh H, Yodoi J, and Yokoyama M. Expression of glutaredoxin in human coronary arteries: its potential role in antioxidant protection against atherosclerosis. Arterioscler Thromb Vasc Biol 21: 1483-1487, 2001.

35. Peltoniemi MJ, Rytila PH, Harju TH, Soini YM, Salmenkivi KM, Ruddock LW, and Kinnula VL. Modulation of glutaredoxin in the lung and sputum of cigarette smokers and chronic obstructive pulmonary disease. Respir Res 7: 133, 2006. 
36. Qin F, Siwik DA, Luptak I, Hou X, Wang L, Higuchi A, Weisbrod RM, Ouchi N, Tu VH, Calamaras TD, Miller EJ, Verbeuren TJ, Walsh K, Cohen RA, and Colucci WS. The polyphenols resveratrol and S17834 prevent the structural and functional sequelae of diet-induced metabolic heart disease in mice. Circulation 125: 1757-1764, s1-s6, 2012.

37. Reynaert NL, Wouters EF, and Janssen-Heininger YM. Modulation of glutaredoxin-1 expression in a mouse model of allergic airway disease. Am J Respir Cell Mol Biol 36: 147-151, 2007.

38. Ronchi JA, Figueira TR, Ravagnani FG, Oliveira HC, Vercesi AE, and Castilho RF. A spontaneous mutation in the nicotinamide nucleotide transhydrogenase gene of C57BL/6J mice results in mitochondrial redox abnormalities. Free Radic Biol Med 63: 446-456, 2013.

39. Sabens EA, Distler AM, and Mieyal JJ. Levodopa deactivates enzymes that regulate thiol-disulfide homeostasis and promotes neuronal cell death: implications for therapy of Parkinson's disease. Biochemistry 49: 2715-2724, 2010.

40. Saijo K, Winner B, Carson CT, Collier JG, Boyer L, Rosenfeld MG, Gage FH, and Glass CK. A Nurr1/CoREST pathway in microglia and astrocytes protects dopaminergic neurons from inflammation-induced death. Cell 137: 47-59, 2009.

41. Salter MW and Beggs S. Sublime microglia: expanding roles for the guardians of the CNS. Cell 158: 15-24, 2014.

42. Samarakoon PS, Sorte HS, Kristiansen BE, Skodje T, Sheng Y, Tjonnfjord GE, Stadheim B, Stray-Pedersen A, Rodningen OK, and Lyle R. Identification of copy number variants from exome sequence data. BMC Genomics 15: 661, 2014.

43. Shao D, Fry JL, Han J, Hou X, Pimentel DR, Matsui R, Cohen RA, and Bachschmid MM. A redox-resistant sirtuin1 mutant protects against hepatic metabolic and oxidant stress. J Biol Chem 289: 7293-7306, 2014.

44. Shelton MD, Distler AM, Kern TS, and Mieyal JJ. Glutaredoxin regulates autocrine and paracrine proinflammatory responses in retinal glial (muller) cells. J Biol Chem 284: 4760-4766, 2009.

45. Shelton MD, Kern TS, and Mieyal JJ. Glutaredoxin regulates nuclear factor kappa-B and intercellular adhesion molecule in Muller cells: model of diabetic retinopathy. J Biol Chem 282: 12467-12474, 2007.

46. Singleton AB, Farrer M, Johnson J, Singleton A, Hague S, Kachergus J, Hulihan M, Peuralinna T, Dutra A, Nussbaum R, Lincoln S, Crawley A, Hanson M, Maraganore D, Adler C, Cookson MR, Muenter M, Baptista M, Miller D, Blancato J, Hardy J, and Gwinn-Hardy K. alpha-Synuclein locus triplication causes Parkinson's disease. Science 302: 841, 2003.

47. Smith GA, Rocha EM, Rooney T, Barneoud P, McLean JR, Beagan J, Osborn T, Coimbra M, Luo Y, Hallett PJ, and Isacson O. A Nurr1 agonist causes neuroprotection in a Parkinson's disease lesion model primed with the toll-like receptor 3 dsRNA inflammatory stimulant poly(I:C). PLoS One 10: e0121072, 2015.

48. Talmadge JE, Phillips H, Schneider M, Rowe T, Pennington $\mathrm{R}$, Bowersox $\mathrm{O}$, and Lenz $\mathrm{B}$. Immunomodulatory properties of recombinant murine and human tumor necrosis factor. Cancer Res 48: 544-550, 1988.

49. Toye AA, Lippiat JD, Proks P, Shimomura K, Bentley L, Hugill A, Mijat V, Goldsworthy M, Moir L, Haynes A, Quarterman J, Freeman HC, Ashcroft FM, and Cox RD. A genetic and physiological study of impaired glucose homeostasis control in C57BL/6J mice. Diabetologia 48: 675-686, 2005.
50. Tufekci KU, Meuwissen R, Genc S, and Genc K. Inflammation in Parkinson's disease. Adv Protein Chem Struct Biol 88: 69-132, 2012.

51. Ullevig S, Zhao Q, Lee CF, Seok Kim H, Zamora D, and Asmis R. NADPH oxidase 4 mediates monocyte priming and accelerated chemotaxis induced by metabolic stress. Arterioscler Thromb Vasc Biol 32: 415-426, 2012.

52. Wang $\mathrm{H}, \mathrm{Qu} \mathrm{H}$, and Deng H. Plasma HMGB-1 levels in subjects with obesity and type 2 diabetes: a cross-sectional study in China. PLoS One 10: e0136564, 2015.

53. Wang W, Wang X, Fujioka H, Hoppel C, Whone AL, Caldwell MA, Cullen PJ, Liu J, and Zhu X. Parkinson's disease-associated mutant VPS35 causes mitochondrial dysfunction by recycling DLP1 complexes. Nat Med 22: 54-63, 2016.

54. Weisbrod RM, Shiang T, Al Sayah L, Fry JL, Bajpai S, Reinhart-King CA, Lob HE, Santhanam L, Mitchell G, Cohen RA, and Seta F. Arterial stiffening precedes systolic hypertension in diet-induced obesity. Hypertension 62: 1105-1110, 2013.

55. Xie HR, Hu LS, and Li GY. SH-SY5Y human neuroblastoma cell line: in vitro cell model of dopaminergic neurons in Parkinson's disease. Chin Med J (Engl) 123: 1086-1092, 2010.

56. Zhang $\mathrm{P}$ and Tian B. Metabolic syndrome: an important risk factor for Parkinson's disease. Oxid Med Cell Longev 2014: 729194, 2014.

57. Zhang Y, James M, Middleton FA, and Davis RL. Transcriptional analysis of multiple brain regions in Parkinson's disease supports the involvement of specific protein processing, energy metabolism, and signaling pathways, and suggests novel disease mechanisms. Am J Med Genet B Neuropsychiatr Genet 137b: 5-16, 2005.

Address correspondence to: Prof. John J. Mieyal Department of Pharmacology

School of Medicine

Case Western Reserve University

WRT 300

2109 Adelbert Road

Cleveland, $\mathrm{OH}$ 44106-4965

E-mail: jjm5@case.edu

Date of first submission to ARS Central, December 3, 2015; date of final revised submission, May 21, 2016; date of acceptance, May 23, 2016.

Abbreviations Used
Ad-EV $=$ empty adenovirus
Ad-Grx $1=$ adenovirus expressing the Glutaredoxin- 1
protein
$\mathrm{CNS}=$ central nervous system
$\mathrm{CNV}=$ copy number variant
$\mathrm{DA}=$ dopaminergic
DDAO $=$ 7-hydroxy-9H-(1,3-dichloro-9,9-
$\quad$ dimethylacridin-2-one)
DMEM $=$ Dulbecco's Modified Eagle Medium
DTT $=$ dithiothreitol
$\mathrm{ECF}=$ enhanced chemical fluorescence
$\mathrm{FBS}=$ fetal bovine serum




\section{Abbreviations Used (Cont.)}

GLRX = glutaredoxin-1 gene

glrx $1=$ glutaredoxin- 1 mRNA

Grx1 = glutaredoxin-1 (thioltransferase)

$\mathrm{GSH}=$ glutathione

HFHS = high-fat high sugar

IKK $\beta=$ inhibitor of nuclear factor kappa-B kinase subunit beta

IL-1 $\beta=$ interleukin 1 beta

IL-6 = interleukin 6

$\mathrm{I} \kappa \mathrm{B} \alpha=$ nuclear factor of kappa light polypeptide gene enhancer in B-cells inhibitor, alpha

$\mathrm{JNK}=\mathrm{c}$-Jun $\mathrm{N}$-terminal kinase
LPS = lipopolysaccharide

MPTP = 1-methyl-4-phenyl-1,2,3,6-tetrahydropyridine

$\mathrm{NADPH}=$ nicotinamide adenine dinucleotide phosphate

$\mathrm{NF}-\kappa \mathrm{B}=$ nuclear factor kappa-light-chain-enhancer of activated B cells

Nurr1 = nuclear receptor related-1

$\mathrm{PARP}=$ poly (ADP-ribose) polymerase

$\mathrm{PD}=$ Parkinson's disease

$\mathrm{PVDF}=$ polyvinylidene fluoride

TGF- $\beta=$ transforming growth factor beta

$\mathrm{TH}=$ tyrosine hydroxylase

tnf $a=\mathrm{TNF}-\alpha$ mRNA

$\mathrm{TNF}-\alpha=$ tumor necrosis factor-alpha 